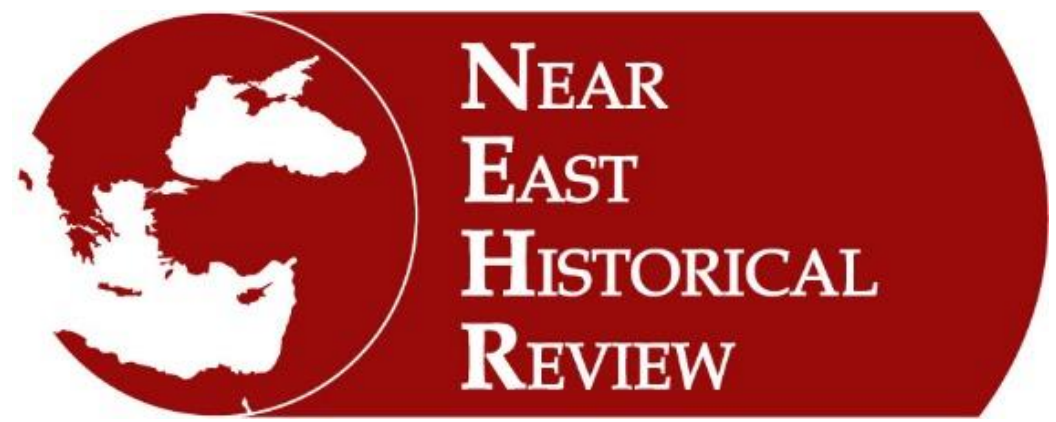

\title{
19. YÜZYILDA GOLOS KAZASI'NDA YAŞAM
}

Life in Golos Kaza in the 19th Century

\author{
Merve Yörükoğulları \\ Amasya Üniversitesi, Türkiye \\ e-mail: mrvcyd19@gmail.com \\ ORCID ID: orcid.org/ 0000-0002-4450-2518
}

Near East Historical Review

10/2, April - Nisan 2020

e-ISSN: 2717-6363 (Online)

www.nehrreview.com

\author{
Article Type - Makale Türü : Research Article / Araştırma Makalesi \\ Received Date-Geliş Tarihi : 1.03 .2020 \\ Accepted Date - Kabul Tarihi : 12.04 .2020 \\ Pages-Sayfa : 145-171 \\ doi : http://dx.doi.org/10.29228/nehrreview.42856
}

\footnotetext{
Citation-Atıf : Merve Yörükoğulları, "19. Yüzyılda Golos Kazası'nda Yaşam", Near East Historical Review, 10/2, April 2020, pp. $145-171$
} 



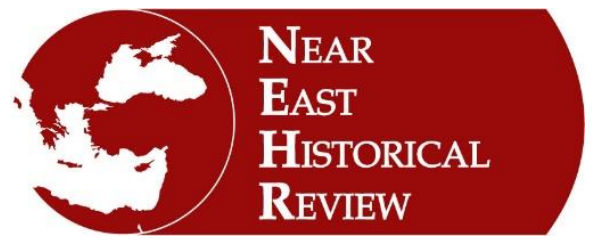

Near $\boldsymbol{E}$ ast Historical Review

10/2, April - Nisan 2020

145-171

\title{
19. YÜZYILDA GOLOS KAZASI'NDA YAŞAM*
}

\author{
Life in Golos Kaza in the 19th Century
}

Merve Yörükoğulları

Amasya Üniversitesi, Türkiye

\section{Öz}

19. yüzyıl dünya genelinde değişim ve dönüşümlerin yaşandığ 1 bir dönemdir. Bu dönemde Tanzimat'ın ilanıyla birlikte Osmanlı İmparatorluğu'nda önemli gelişmelerin yaşandığı görülmektedir. Sanayileşmiş devletler hammadde ve pazar arayışına girdiler. $\mathrm{Bu}$ süreçten en fazla etkilenen ülkelerden birisi de Osmanlı Devleti olmuştur. 19. yüzyılda yaşanan gelişmelerin en somut örneği kent yapılarında meydana gelen gelişmeler olmuştur. Özellikle liman kentleri değişimin en fazla yaşandığı yerler olmuştur. $\mathrm{Bu}$ bağlamda liman kentleri diğer kentlere göre daima ön planda olmuştur. Tırhala sancağına bağlı küçük bir yerleşim birimi olan Golos, 19. yüzyılın ortalarından itibaren hızlı bir şekilde modernleşme sürecine girmiştir. Kısa bir zaman içerisinde büyük bir gelişme göstererek modern bir liman kenti haline gelmiştir.

Bu makalede Golos kazasının 19. yüzyılda yaşadığı değişim süreci ele alınmıştır. Elde edilen veriler ışığında Golos'un demografik yapısı incelenerek Müslim ve gayrimüslim nüfus oranları ortaya çıkarılmaya çalışılmıştır. Aynı zamanda toplumsal hayatı etkileyen olaylar hakkında bilgi verilmiştir. Kazanın eğitim durumu dini ve kültürel yapısı ortaya konmaya çalışılmıştır.

Anahtar Kelimeler: Osmanlı Devleti, Golos, Tanzimat, Sosyal Hayat

\begin{abstract}
The $19^{\text {th }}$ century is a period in which changes and transformation stake place across the world. It is seen that important development stok place in the Ottoman Empire with the declaration of Tanzimat in this period. Industrialized states searched for raw materials and markets. One of the countries most affected by this process was the Ottoman State. The most concrete example of the developments in the $19^{\text {th }}$ century has been the development soccurring in urban buildings. Port cities, in particular, were the places where the change was experienced the most. In this context, port cities have always been at the forefront compared to other cities. Golos, which is a small settlement connected toTirhala Sanjak, entered the modernization process rapidly since the mid- $19^{\text {th }}$ century. It has developed in a short time and has become a modern port city.

In this article, the change process of the Golos kaza in the $19^{\text {th }}$ century is discussed. In the light of the data obtained, the demographic structure of Golos was examined and Muslim and nonMuslim population ratios were tried to be revealed. At the same time, information was given about the events that affect social life. Educational and religious and cultural structure of the district was tried to be revealed.
\end{abstract}

Keywords: Ottoman Empire, Golos, Tanzimat, Social Life

\footnotetext{
* Bu çalışma yazarın “Tanzimat Döneminde Golos Kazası 'nın Sosyal ve Ekonomik Durumu” başl1lı Yüksek Lisans tezinden ütetilmiştir.
}

Near East Historical Review www.nehrreview.com 


\section{Giriş}

Ticaretin gelişmesi ile birlikte zenginlik feodal toprak sahiplerinin ellerinden çıkıp tüccarların eline geçmiştir. Feodal düzenin zayıflamasıyla beraber ticari gücü ellerinde bulunduran tüccarlar artık kent ve ülkeler arasında ticaret yapmaya başlamıştır. Feodalizmin yerini alan ticari kapitalizm, kentlerin gelişmesinde önemli bir etken olmuştur. Ticaretin artmasıyla kentler önem kazanmaya başlamış; kentler geliştikçe de ticaretin hacmi artmıştır. Dolayısıyla birbirini etkileyen süreç yaşanmıştır. Kapitalizmin gelişmesiyle Avrupa Devletleri ucuz hammadde bulabilmek için pazar arayışı içine girmişlerdir. ${ }^{1}$ Sanayileşen ülkelerin hammadde ve pazar arayışından Osmanlı Devleti de etkilenmiştir. Sanayileşmiş ülkeler Osmanlı Devleti'ni önemli bir hammadde kaynağı ve pazar alanı olarak görmüşlerdir. ${ }^{2}$ 1838'de İngiltere ile imzalanan Balta Limanı Anlaşması ile gümrük vergileri yeniden belirlenmiş, Osmanlı ülkesi Avrupalıların açık pazarına dönüşmüştür. ${ }^{3}$

Kapitalizm ve merkez-çevre ilişkisi sadece sanayileşmiş ülkelerin değil henüz sanayileşememiş olan ülkelerin şehirlerinde de değişimlere neden olmuştur. 1839 yılından beri reform çabası içerisinde olan Osmanlı Devleti'nde modern kent planlaması, sanayileşmede geciktiği için Batı ülkelerinden daha farklı bir gelişme göstermiştir. ${ }^{4}$ Ancak Osmanlı Devleti'nin kapitalist dünya ekonomisinden etkilenmeye başlamasıyla birlikte Tanzimat'ın şehir planlaması üzerine etkisi 1850 'lerden sonra daha fazla hissedilmeye başlanmıştır. ${ }^{5}$ Tanzimat'ın şehir yapısında meydana getirdiği değişime en iyi ayak uyduran yerler ise liman şehirleri olmuştur. ${ }^{6}$

19. yüzyılda, gerçekleşen kapitalist sistem ile birlikte liman şehirleri önem kazanmaya başladı. Tüccarların girişimleriyle birlikte liman şehirlerinde ticaret gelişti. ${ }^{7}$ Ulaşımın kolay olması liman şehirlerinin ayrıcalıklı yerler haline gelmesini sağladı. Avrupa'ya olan yakınlıklarından dolayı Balkanlar ve Batı Anadolu'daki kıyı şehirleri daha da geliştiler. ${ }^{8}$ Nitekim Osmanlı kentlerinde meydana gelen kentsel dönüşüm 1860'l1 y1llardan sonra liman şehirlerinde kendisini daha çok belli etme imkânı bulmuştur. ${ }^{9}$

İçeri alandaki kentlere göre sanayinin geliştiği liman kentleri nüfus yoğunluğunun da en fazla yaşandığı yerler olmuştur. Osmanlı Devleti'nin kapitalizme veya kapitalist sisteme dâhil olmasıyla modernleşme özellikle liman şehirlerinde şehir nüfusunun artmasına buna bağlı olarak da yeni iskân alanlarının açılmasını sağlamıştır. ${ }^{10}$ Liman şehirlerinde nüfusun bu denli artmasının nedeni, ekonomik faaliyetlerin oralarda daha yoğun olmasından kaynaklanmaktadır. Bu durum iç şehirlerden liman şehirlerine insanları çekmiştir. ${ }^{11}$

\footnotetext{
${ }^{1}$ İbrahim Serbestoğlu- Mim Sertaç Tümtaş “II. Abdülhamit Dönemi’nde Bir Liman Kenti: Dedeağaç”, Ubtas bled Slovenya, s. 2.

${ }^{2}$ Mehmet Mazak- Aylin Doğan, Osmanlı Arşiv Vesikaları ve Fotoğraflarla Mersin Liman Tarihi, Yeditepe Yayınları, İstanbul 2014, s. 248.

${ }^{3}$ Mübahat Kütükoğlu, Osmanl- Ingiliz İktisadi Münasebetleri (cilt 2), Edebiyat Fakültesi Yayınevi, İstanbul 1976, s. 4-5.

${ }^{4}$ Ergül Ballı, "Modernleşme Çağında Karadeniz'de Bir Liman Kenti: Bartın”, ODÜ Sosyal Bilimler Araştırmalar Dergisi, 5/12, 2015, s. 514.

5 İbrahim Arslan, "19. Yüzyılda Balkanlarda Bir Liman Şehri: Kavala”, History Studies, 2/3, 2010, s. 34.

${ }^{6}$ Tülin Selvi Ünlü, On Dokuzuncu Yüzyıldan Yirminci Yüzyıla Doğu Akdeniz Liman Kentlerinde Mekânın Dönüşümü: Volos, Patras ve Mersin, Yayımlanmamış Yüksek Lisans Tezi, Dokuz Eylül Üniversitesi, Fen Bilimleri Enstitüsü, İzmir 2016, s. 13.

${ }^{7}$ Çağlar Keyder vd., "Doğu Akdeniz'de Liman Kentleri 1800- 1914”, Osmanlı Imparatorluğu’nda Liman Kentleri: Bazı Kuramsal ve Tarihsel Perspektifler, Editör: Çağlar Keyder vd., Tarih Vakfı Yurt Yayınları, İstanbul 1994 s. 121. ${ }^{8}$ T.S Ünlü, $a$. g. e., s. 100.

9 İlhan Tekeli, “ Kent Planlaması ve Kent Araştırmaları”, Cumhuriyet Dönemi'nde Türkiye'de Bilim Türkiye Bilimler Akademisi, Ankara 1998, s. 305.

${ }^{10}$ Nedim İpek, “ Orta ve Doğu Karadeniz Limanlarındaki Ticari Faaliyetlerin Kent Nüfusuna Etkisi (1838- 1900)”, Uluslararası Karadeniz Incelemeleri Dergisi, 1/1, 2006, s. 109., E. Ball1, a. g. m., s. 514,

${ }^{11}$ Ç. Keyder, a. g. e., s. 138.
} 
Liman şehirlerinin en belirgin özelliği ise nüfusunun büyük bir bölümünü yabancıların oluşturmasıydı. Osmanlı liman şehirlerinde bu bağlamda çok sayıda ecnebi tüccarı görmek mümkündür. Üstelik ticarete ve şehrin gelişmesine bağlı olarak liman şehirlerinde etnik ve dini kozmopolitlik iç bölgelerdeki yerleşim birimlerinden çok daha fazla göze çarpmaktadır. ${ }^{12}$

19. yüzyıl, Osmanlı Doğu Akdeniz şehirleri içinde yeni bir dönemin başlangıcı olmuştur. Doğu Akdenizdeki şehir yapısında meydana gelen değişiklikler Yanya vilayeti dâhilinde ki Tesalya' da bulunan Osmanlı şehirlerinde de görülmeye başlamıştır. ${ }^{13}$

Golos, 19. yüzyılın ortalarına kadar Tırhala sancağına bağlı küçük bir yerleşim birimi idi. 1830'lu yıllara kadar bir kale içerisinde bulunan şehir bu tarihten sonra hızlı bir şekilde modernleşme sürecine girmiştir. Bu denli hızlı bir gelişme ve modernleşme Golos kazasının coğrafi yapısından kaynaklanmaktadır. ${ }^{14}$ 19. yüzyılda ticari faaliyetlerin artmasıyla birlikte Golos'un şehir yapısında da değişim başlamışıtır. Ayrıca, Tanzimat'ın etkileri ve Yunan hududuna yakınlığ 1 şehrin modernleşmesinde etkili olmuştur. ${ }^{15}$

\section{Golos Kazasında Yașam}

\section{1. Nüfus}

Nüfus, Arapça nefs kelimesinin çoğulu olup "nefis; ruh, can, hayat" anlamlarına gelmektedir. Nüfus daha çok bir bölgede yaşayan insanları ifade etmek için kullanılmaktadır. "Bir yerde oturan, ikamet eden" anlamındaki sâkinin çoğulu olan sükkân/ sekene de nüfus karşıllı̆ında kullanılmaktadır. ${ }^{16}$ Toplumların sosyal ve ekonomik yapısının şekillenmesinde en önemli faktörlerden birisi nüfustur. Bir toplumdaki nüfusun artıp azalması ile nüfus üretim ilişkisi savaşların ve diğer tarihi olayların bazen sebepleri bazen de sonuçları arasında yer almaktadır. Nüfus, üretim ve tüketim konusunda, iş gücü, ekonomik, askeri ve daha birçok yönüyle ülkelerin önem verdiği kaynaklardan biridir. ${ }^{17}$ Osmanlı Devleti de ilk dönemlerden itibaren nüfus sayımına büyük önem vermiştir. Klasik dönemden itibaren yapılan nüfus sayımlarının temel amacı toprak miktarının belirlenmesine yönelik olmuştur. Devlet ilk dönemlerde otuz yılda bir yaptığı tahrirler ile nüfusu belirlemek adına sayımlar gerçekleştirmiştir. Bu uygulama zaman içerisinde yasal bir hale getirilmiştir. ${ }^{18}$

Osmanlı Devleti'nde ilk nüfus sayımına 1826- 1828 yılları arasında başlanmıştır. Fakat o tarihlerde Rusya ile olan savaş durumundan dolayı sayım yarım kalmıştır. Savaşın bitimiyle birlikte Osmanlı Devleti'nde modern anlamda ilk nüfus sayımı 1831 yılında tamamlanmıştır. ${ }^{19}$ $\mathrm{Bu}$ dönemde yapılan nüfus sayımlarında kişi yerine hane esas alınmıştır. Gerçekleştirilen sayımlar sırasında belli bir yaşa gelmiş erkek nüfus sayılmıştır. Kadınlar ve çocuklar ile birlikte hiç kazancı olmayan yaşlılar ise sayıma dâhil edilmemiştir. 1831 nüfus sayımının amacı ülkede vergi

\footnotetext{
12 Ç. Keyder, a. g. e., s. 139.; Çağlar Keyder vd., Belle Epoque ve Liman Kentleri. B. Kolluoğlu ve M. Toksöz, Osmanlılardan Günümüze Doğu Akdeniz Kentleri, Türkiye İş Bankası Kültür Yayınları İstanbul 2015, s. 24.

${ }^{13}$ T. S Ünlü, a. g. e., s. 10.; Ferdi Çiftçioğlu, XIX. Yüzyılda Osmanlı Devleti İçin Balkanlarda Stratejik Bir Liman Kenti: Golos, Journal of Social and Humanities Sciences Research, 5/25, 2018, s. 2301.; İlkay Erken, Yanya Sancağı'nın İdari Yapısı ve Yerleşim Birimleri (1867- 1913), Yayımlanmamış Doktora Tezi, Ondokuz Mayıs Üniversitesi, Sosyal Bilimler Enstitüsü, Samsun 2019, s. 58.

${ }^{14}$ F. Çiftçioğlu, a. g. m., s. 2300., Alexandra Yerolympos, Planning Reform in the European Provinces of the Ottoman Empire at the end of the $19^{\text {th }}$ century, Economy and Society on Both Shores of the Aegean, 2010, s. 9.

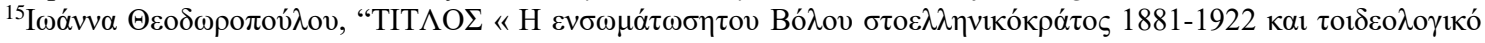

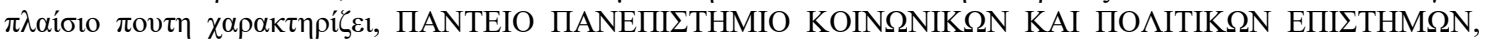

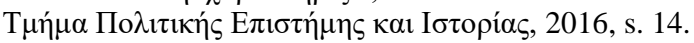

${ }^{16}$ Nebi Bozkurt, "Nüfus", Diyanet Vakfi İslam Ansiklopedisi, Cilt: 33, Türkiye Diyanet Vakfı Yayınları, İstanbul 2007, s. 293.

${ }^{17}$ Bekir Akşit, XIX. Yüzyıl Ortasında Uluborlu Kazasının Nüfus Yapısı, Yayımlanmamış Yüksek Lisans Tezi, Selçuk Üniversitesi, Sosyal Bilimler Enstitüsü, Konya 2016, s. 1.

${ }^{18}$ Enver Ziya Karal, Osmanlı Imparatorluğunda İlk Nüfus Sayımı 1931, Ankara 1995, s. 6.

${ }^{19}$ E.Z. Karal, a. g. e., s. 9- 10.
} 
verebilecek ve askerlik yapabilecek nüfus miktarını tespit etmektir. ${ }^{20}$ Bir takım eksiklik ve aksaklıklara rağmen yapılan bu nüfus sayımı ülke dâhilinde yaşayan Müslüman ve gayrimüslim nüfusu ortaya çıkarması bakımından önemlidir. Osmanlı Devleti'nde toprak yazımı amacı güdülmeden yapılan ilk nüfus sayımı olarak kabul edilmektedir. ${ }^{21} 1844$ yılında tamamen askeri ihtiyaçlar doğrultusunda bir sayım daha yapılmıştır. ${ }^{22}$

Osmanlı Devleti'nde yapılan nüfus sayımları hep eksik olmuştur. Esas olarak Osmanlı Devleti'nde sağlıklı bir nüfus sayımı 1877- 1878 Osmanlı- Rus Harbi sonrasında yapılabilmiştir. Siyasi durumun düzelmesinin ardından nüfus sayımı ile ilgili yapılan hukuki bir düzenlemeyle Şura-yı Devlet tarafindan hazırlanan "Sicil-i Nüfus Nizamnamesi" 4 Eylül 1881 tarihinde yürürlüğe girmiştir. ${ }^{23} \mathrm{Bu}$ tarihten itibaren yapılan sayımlarda nüfus; yaşa, cinsiyete, medeni duruma, etnik yapı, dinsel durum, meslek ve doğum yerlerine göre sınıflandırılmıştır. ${ }^{24} \mathrm{Bu}$ doğrultuda 1882 yılında yapılan sayımlara artık kadınlarda dâhil edilmiştir. ${ }^{25}$

Bir kent hayatının iyi anlaşılabilmesi için orada yaşayan nüfusun tespit edilerek özelliklerinin bilinmesi gerekmektedir. Şehir nüfusunun miktarı, cinsiyeti, hareketliliği, iş- güç durumları hakkında edinilen bilgiler o toplumun sosyal ve ekonomik konumunun belirlenmesinde oldukça etkilidir. $^{26}$

Tesalya bölgesindeki Müslüman nüfusun çoğunu Anadolu'dan Rumeli’ye nakledilen Türkmenler oluşturmuştur. Bununla birlikte Türkler, Tatarlar, Arnavut ve Çerkesler olmak üzere dört etnik gruba ayrılmaktadır. ${ }^{27}$ Müslümanların dışında nüfusun büyük çoğunluğunu Rum ve Ulahların oluşturduğu Hristiyanlar meydana getirmektedir. ${ }^{28}$

Tesalya Bölgesi'nde bulunan Golos'ta 1800'lü yıllarda kale içerisindeki yerleşimde 150 Müslüman ailenin yanı sıra limanda çalışan ve kalenin dışında yaşayan çok sayıda Yahudi nüfus bulunmaktaydı. ${ }^{29}$ Golos 1830'ların başlarına kadar henüz Yenişehir-i Fenar kazasına bağlı bir nahiye idi. Ancak burada ticari faaliyetlerin yoğunluk kazanması Golos'un hızlı bir şekilde gelişmesini sağlamıştır. Ticari yapıda meydana gelen bu hareketlilik nüfusun artışında etkili olmuştur. Golos özellikle tüccarların yerleştikleri bir liman kenti haline gelmiştir. ${ }^{30}$

\footnotetext{
${ }^{20}$ Mutullah Sungur, “XIX. Yüzyılda Osmanlı Devleti’nde Nüfus ve Nüfus Sayımları”, Osmanlı, Cilt:4, Yeni Türkiye Yayınlar1, Ankara 1999, s. 558- 559.

${ }^{21}$ B. Akşit, a. g. e., s. 7.

${ }^{22}$ Tevfik Çavdar, "Osmanlı Döneminde Nüfus Bilgileri”, Osmanlı, Cilt: 4, Yeni Türkiye Yayınları, Ankara 1999, s. 554- 555.

${ }^{23}$ Ali Güler, “ Osmanlı Devleti'nin Son Yıllarında Türkiye'nin Demografik Durumuna Genel Bir Bakış”, Osmanll, Cilt: 4, Yeni Türkiye Yayınları, Ankara 1999, s. 568.

${ }^{24}$ B. Akșit, a. g. e., s. 8.

25 T. Çavdar, a. g. m., s. 555.

${ }^{26}$ Selim Özcan, Tanzimat Döneminde Sinop'un Sosyal ve Ekonomik Durumu, Yayımlanmamış Yüksek Lisans Tezi, Ondokuz Mayıs Üniversitesi, Sosyal Bilimler Enstitüsü, Samsun 2007, s. 43.

27 İbrahim Serbestoğlu, Yunanistan'a Geçiş Sürecinde Tesalya Müslümanlarının Durumu, Belleten, 78/ 283, 2014, s. 1076.

${ }^{28}$ Şemsettin Sami, “Tesalya”, Kamûsu'l- Âlâm, Cilt:3, Mihran Matbaası, İstanbul 1308, s. 1652.

${ }^{29}$ Tülin Selvi Ünlü- Emel Göksu, "Osmanlı'dan Ulus- Devlete Doğu Akdeniz Liman Kentlerinde Mekâna Müdahale ve Kent Kimliğindeki Değişim- Mersin ve Volos Örneği” METU JFA, 1/5, 2018, s. 25.

${ }^{30}$ Ferdi Çiftçioğlu, XIX. Yüzyılda Tırhala Sancağı (1821- 1881), Yayımlanmamış Doktora Tezi, Manisa Celal Bayar Üniversitesi, Sosyal Bilimler Enstitüsü, Manisa 2018, s. 163.
} 
Tablo 1. 1830 Yılı Golos Nahiyesi Müslim-Gayrimüslim Nüfusu ${ }^{31}$

\begin{tabular}{lll}
\hline & Hane & Kişi sayıs1 \\
\hline Müslim & 138 & 247 \\
Gayri Müslim & 1.776 & 3.671 \\
Toplam & 1.914 & 3.918 \\
\hline
\end{tabular}

1830 yılı nüfus sayımlarına göre Golos'ta toplam 3.918 kişi yaşamaktadır. Golos'taki nüfusun büyük çoğunluğunu ise gayrimüslimler oluşturmaktadır. ${ }^{32}$

Tablo 2. 1843 Yllı Golos Nahiyesi Müslüman Nüfusu ${ }^{33}$

\begin{tabular}{lll}
\hline \multicolumn{1}{c}{ Yer } & Hane & Kişi Sayıs \\
\hline Erilasti karyeleri & 1 & 23 \\
Golos Karyesi & 471 & 1003 \\
Golos Bahçeleri & 7 & 152 \\
Golos Kalesi & 1 & 32 \\
Golos Kalesi İslam & 5 & 40 \\
Kıptisi & & \\
Golos Merkez & 72 & 104 \\
Alason Karyesi & 112 & 227 \\
AnyelosKayesi & 89 & 209 \\
Atafenos Karyesi & 154 & 314 \\
Ayalorşar Karyesi & 296 & 583 \\
Ayayorgi Karyesi & 273 & 595 \\
BirçatYancıyan karyesi & 1 & 42 \\
ÇıngarAda Karyesi & 368 & 758 \\
Darbasar Karyesi & 189 & 403 \\
Drake Karyesi & 364 & 888 \\
Elason Karyesi & 33 & 47 \\
Ergılasti Karyesi & 393 & 686 \\
Gıraşan Karyesi & 74 & 157 \\
\hline
\end{tabular}

${ }^{31}$ F. Çiftçioğlu, a.g.t., s. 136.

${ }^{32}$ F. Çifţ̧̧ioğlu, a.g.t., s. 136.

${ }^{33}$ F. Çiftçioğlu, a.g.t.,s. 164- 165. 


\begin{tabular}{|c|c|c|}
\hline Givas Karyesi & 205 & 490 \\
\hline Karabaş Karyesi & 85 & 109 \\
\hline Karaşahor Karyesi & 207 & 487 \\
\hline Lafyekos Karyesi & 254 & 559 \\
\hline Mikraraç Karyesi & 80 & 210 \\
\hline Milas Karyesi & 238 & 450 \\
\hline Muras Karyesi & 117 & 234 \\
\hline Navaz Karyesi & 106 & 194 \\
\hline Nihor Karyesi & 239 & 489 \\
\hline Osturfelu Karyesi & 23 & 43 \\
\hline $\begin{array}{l}\text { Karye-i Parakendayan } \\
\text { dönemlik işçiler }\end{array}$ & 1 & 51 \\
\hline Portariye Karyesi & 69 & 160 \\
\hline Vizici Karyesi & 153 & 347 \\
\hline Zağra Karyesi & 110 & 294 \\
\hline Ayatanaşi Mahallesi & 55 & 117 \\
\hline Ayayorgi Mahallesi & 71 & 168 \\
\hline Ayayorgi Mahallesi & 112 & 311 \\
\hline Berdar Mahallesi & 26 & 55 \\
\hline BirçatYanciyan Mahallesi & 1 & 47 \\
\hline İsaki Mahallesi & 63 & 134 \\
\hline İsteyavas Mahallesi & 58 & 132 \\
\hline Kiryaki Mahallesi & 80 & 202 \\
\hline Kokrak Mahallesi & 66 & 164 \\
\hline Malis Mahallesi & 105 & 223 \\
\hline Masluh Mahallesi & 64 & 133 \\
\hline Mikraniçe Mahallesi & 135 & 276 \\
\hline Mişretetka Mahallesi & 56 & 105 \\
\hline Orta Mikraniçe Mahallesi & 104 & 297 \\
\hline ParagezeyanMahalellesi & 65 & 125 \\
\hline Pazar Mahallesi & 88 & 207 \\
\hline Poriyo Mahallesi & 109 & 265 \\
\hline
\end{tabular}




\begin{tabular}{lll}
\hline PorponoMahallesi & 55 & 102 \\
Soytaru Mahallesi & 110 & 295 \\
Tano Mahallesi & 85 & 187 \\
Tunca Mahallesi & 126 & 134 \\
Yukar1 Mahalle & 110 & 268 \\
Kanalaki Mahallesi & 75 & 217 \\
TOPLAM & 6.675 & 14.544 \\
\hline
\end{tabular}

Tabloya bakıldığında 1843yılında Golos nahiyesinde 6.675 hanede 14.544gayrimüslim nüfus bulunmaktadır. ${ }^{34} 1844$ yılında şehrin yeniden inşasıyla birlikte nahiyeye Hristiyan nüfus da eklenmiştir. Artık Golos'ta Müslüman, Yahudi ve Rumların yanı sıra Katolik nüfus da birlikte yaşamaya başlamışıır. ${ }^{35}$

Tablo 3. 1847 Yılı Golos Nahiyesi Gayrimüslim Nüfusu ${ }^{36}$

\begin{tabular}{lll}
\hline Yer & Hane & Kişi Sayıs \\
\hline Golos Bahçesi & 87 & 185 \\
Ahinon Karyesi & 71 & 155 \\
Alodater Karyesi & 328 & 717 \\
Anyelos Karyesi & 112 & 262 \\
Ayayorgi Karyesi & 319 & 775 \\
Baştanka Karyesi & 59 & 118 \\
Çıarata Karyesi & 45 & 97 \\
Drake Karyesi & 426 & 1.069 \\
Ergılasti Karyesi & 391 & 837 \\
Eski Karyesi & 70 & 166 \\
Fetihor Karyesi & 235 & 599 \\
Karabaş Karyesi & 103 & 197 \\
Kemreşa Karyesi & 82 & 187 \\
Kisvese Karyesi & 265 & 632 \\
Lafkoz Karyesi & 289 & 722 \\
Makdara Karyesi & 93 & 221 \\
Metrah Karyesi & 65 & 140 \\
\hline
\end{tabular}

${ }^{34}$ F. Çiftçioğlu, a. g. t., s. 164- 165.

35 T. S. Ünlü- E. Göksu, a. g. m., s. 25.

${ }^{36}$ F. Çiftçioğlu, a. g. t., s. 165- 166. 
152

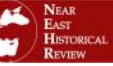

$10 / 2$

April 2020

\begin{tabular}{|c|c|c|}
\hline Mikraniçe Karyesi & 101 & 246 \\
\hline Miloş Karyesi & 353 & 796 \\
\hline Muras Karyesi & 153 & 366 \\
\hline Nauvaş Karyesi & 107 & 226 \\
\hline Nihor Karyesi & 271 & 610 \\
\hline Porapan Karyesi & 102 & 243 \\
\hline Poştarya Karyesi & 114 & 299 \\
\hline Redebdamir Karyesi & 202 & 462 \\
\hline Vizemposa Karyesi & 149 & 400 \\
\hline Yanekadiş Karyesi & 159 & 382 \\
\hline Yera Karyesi & 33 & 69 \\
\hline Zağdara Karyesi & 134 & 347 \\
\hline Aliğağa Mahallesi & 68 & 155 \\
\hline Anakaş Mahallesi & 141 & 326 \\
\hline Astaya Mahallesi & 72 & 187 \\
\hline Ayagiryani Mahallesi & 97 & 236 \\
\hline Ayatanaş & 52 & 125 \\
\hline $\begin{array}{l}\text { Ayayaraşköy } \\
\text { Mahallesi }\end{array}$ & 180 & 789 \\
\hline Ayayorgi Mahallesi & 151 & 540 \\
\hline Çarşı Mahallesi & 159 & 409 \\
\hline Çeşme Mahallesi & 109 & 561 \\
\hline Çınar Mahallesi & 117 & 289 \\
\hline Kanalaki Mahallesi & 108 & 257 \\
\hline Kokodan Mahallesi & 86 & 198 \\
\hline Malada Mahallesi & 107 & 250 \\
\hline Mitfarşa Mahallesi & 113 & 270 \\
\hline Mivargi Mahallesi & 116 & 301 \\
\hline Pazar Mahallesi & 104 & 255 \\
\hline Tokşar Mahallesi & 136 & 389 \\
\hline Varda Mahallesi & 72 & 142 \\
\hline TOPLAM & 7.246 & 17.204 \\
\hline
\end{tabular}


Yukarıda verilen tabloya göre 1847 'de Golos nahiyesinde 7.246 hanede 17.204 gayrimüslim nüfus bulunmaktadır. Golos’un giderek büyüdüğü ve nüfusunun arttığı görülmektedir. ${ }^{37}$

Giderek genişlemeye başlayan Golos 1848 yılında Yenişehir-i Fenar'dan ayrılarak müstakil bir kaza olmuştur. Golos kazası hızla büyüdüğü ve nüfusu arttı̆gı için 1856 yılında oraya Defter Nazırı olarak ileri gelenlerden Mehmed Efendi aylık 400 kuruş maaş ile tayin edilmiştir. Mehmed Efendi'nin maaşı Golos ahalisinin vergisine eklenmiştir. Golos'a bazı yerlerin de ilave edilmesiyle birlikte alanı daha da genişlemiştir. Bundan dolayı Golos'un Tırhala sancağına bağlı bir kaza olmasındansa doğrudan doğruya Yanya eyaleti'ne bağlı bir kaza olması dahi istenmiştir. ${ }^{38}$

1859 yılında yapılan nüfus sayımına göre Golos'ta 16.490 Müslüman bulunmaktadır. Bu bakımdan Tırhala sancağının Yenişehir-i Fenar'dan sonra ki en fazla Müslüman nüfusuna sahip kazası olmuştur. ${ }^{39}$

Yunanlılar tarafindan ilk resmi nüfus sayım çabası 1876 tarihinde Yenişehir ve Golos'taki Yunan konsolosları tarafından gerçekleştirilmiştir. Yunanlıların bu çabasının altında "Megali İdea" düşüncesi bulunmaktadır. Bir propaganda aracı olarak gördükleri Rumları olabildiğince çok göstermeye çalışmışlardır. 1878 yılında yapılan nüfus sayımına göre Golos'ta 71.985 Hristiyan, 2.675 Müslüman, 650 Yahudi olmak üzere toplam 75.310 kişi bulunmaktadır. Aynı döneme ait Osmanlı Devleti'nin başka bir istatistiğine göre Golos'ta 112 köy, 852 Müslüman ve 36.688 gayrimüslim mevcuttur. ${ }^{40}$

Golos'un Yunanistan'a bırakılmasının ardından 1881 tarihinde tekrar bir nüfus sayımı yapılmıştır. Yunan Devleti'nce yapılan bu sayıma göre Golos şehrinde Hristiyan, Müslüman ve Yahudiler yaşamaktadır. ${ }^{41}$ Golos'ta birçok Yahudi ile birlikte özellikle Türk nüfusu kale içerisinde yoğunlaşmıştır. Kale içerisinde 2.678 erkek, 2.309 kadın olmak üzere toplam 4.987 kişi bulunmaktaydı. Bu Golos'un nüfusunun \%9'unu oluşturmaktadır. ${ }^{42}$ Kale içinin nüfusu 1889 yılında $11.029,1895$ yılında 15.000 ve 1896 'da ise 16.788 kişiye ulaşmıştır. ${ }^{43}$

1897 savaşında Osmanlıların Yunanlıları bozguna uğratmasının ardından Tesalya'da bulunan Rumlar göç etmişlerdi. Ancak Tesalya'nın tekrar Yunanistan'a bırakılmasıyla geri dönen Rumlar Yunan Hükümetinin de desteği ile Müslümanlara karşı katliamlara başlamışlardır. Yaşanan bu baskılar yüzünden Müslümanlar Osmanlı topraklarına göç etmek zorunda kaldılar. ${ }^{44}$ Türk- Yunan savaşının yaşandığı bu dönemde Golos'taki Müslüman nüfusun oranı azalmış olup 1924 yılından itibaren de Müslüman nüfus tamamen silinmiştir. ${ }^{45} 1930$ yılına gelindiğinde kentin nüfusu 30.000 kişiye ulaşmıştır. ${ }^{46}$ Golos'un şehir nüfusu artmaya devam ederek bugün 145.000 kişilik nüfusu ile Yunanistan'ın en büyük altıncı şehridir. ${ }^{47}$

\footnotetext{
${ }^{37}$ F. Çiftçioğlu, a. g. t., s. 165- 166.

${ }^{38}$ Başbakanlık Osmanlı Arşivi (BOA), Sadaret Mektubu Kalemi Meclis-i Vâlâ Evrakı ( A. MKT. MVL), Dosya no: 83, Gömlek no: 5, Tarih: 21 Rebiyülevvel 1273 (19 Kasım 1856).

${ }^{39}$ F. Çiftçioğlu, a. g. m., 2303.

${ }^{40}$ Bülent Akyay, Tesalya Meselesi (1881), Yayımlanmamış Yüksek Lisans Tezi, Ege Üniversitesi, Sosyal Bilimler Enstitüsü, İzmir 2001, s. 62- 63.

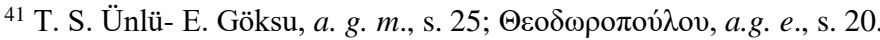

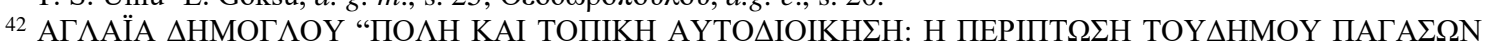
(BO $\Lambda$ OY), 1881- 1944", Doktora Tezi, Yanya Üniversitesi, 2003, s. 58.

${ }^{43} \mathrm{АГ} \Lambda \mathrm{AÏА} \triangle \mathrm{HМОГ \Lambda ОҮ,} \mathrm{a.} \mathrm{g.} \mathrm{e.,} \mathrm{s.} \mathrm{58;} \mathrm{Т.} \mathrm{S.} \mathrm{Ünlü,} \mathrm{a.} \mathrm{g.} \mathrm{e.,} \mathrm{s.} 134$.

44 İbrahim Serbestoğlu, “1897 Türk- Yunan Savaşı'nda Ecnebilerin Zararlarının Tazmini Meselesi”, OTAM, 34, 2013, s. $230-231$

45 T. S. Ünlü- E. Göksu, a. g. m., s. 26.

46 T. S. Ünlü, a.g.e., s. 142.

${ }^{47}$ Evangelia Athanassiou- Chatzipavlou Christodouou, "The City of Volos in the Network of Meditterranean," Cities. Museums in Motion, Symposium Proceeding, University of Thessaly Press, 2015, s. 7.
} 


\section{2. Konsolosluk Faaliyetleri}

Konsolos, Latince "danışmak, istişare etmek, düşünmek" gibi anlamlara gelen consulere fiilinden türetilmiştir. Roma'da önemli devlet meselelerini halk meclisi ile görüşen devlet memurunu ifade etmektedir. Ancak Ortaçağ'da bağlı oldukları devletin yabancı ülkelerdeki bir nevi ticari temsilcisi haline gelmiştir. Ortaçağ' daki bu değişiklik 19. yüzyılda da devam etmiştir ${ }^{48}$ $\mathrm{Bu}$ bakımdan konsolos, bir ülkede kendi vatandaşlarının haklarını ve çıkarlarını koruyan, ticaret ve kültürel etkinliklerini gözeten bir kamu görevlisidir. ${ }^{49}$

18. yüzyılın ikinci yarısından itibaren ticaret ve sanayi alanlarında meydana gelen hızlı gelişmeler ile birlikte, hükümetler konsolosluk kurumuna daha çok önem vermişlerdir. Ticaretin gelişmesiyle beraber yabancı devletler ticaretin etkin olduğu şehirlerde konsolosluk açmaya başlamışlardır. ${ }^{50}$ Özellikle ticari faaliyetlerin yoğun olduğu liman şehirlerinde sürekli konsolosluk kurumları oluşturulmuştur. ${ }^{51}$

Golos ticaretin canlı olduğu bir yer olduğu için yabancı tüccar burada fazlasıyla bulunmaktadır. Bundan dolayı şehirde yabancı konsolosluk kurumları da yer almıştır. Golos'ta 1854 y1lında bir Fransız Konsolosluğu bulunmaktadır. ${ }^{52} 1855$ y1lında ise İngiltere tarafından Mr. John Blont Golos'a konsolos olarak tayin edilmiştir. ${ }^{53}$ Golos'taki İngiliz Baş Konsolosluğu ilk olarak ticari bir amaç için kurulmamıştır. Bu konsolosluk Rusya ile savaşın ardından siyasi düşünceler doğrultusunda ortaya çıkmıştır. 1861 yılında Golos ve Larissa Baş Konsolosluğu birleştirilmiştir.

Tablo 4. 1871'de Golos 'taki Konsolosluklara Dair İngiliz Raporu ${ }^{54}$

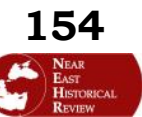

\begin{tabular}{|c|c|c|c|c|c|}
\hline Ülke & Statü & $\begin{array}{l}\text { Ticari } \\
\text { Konumu }\end{array}$ & Personel & $\begin{array}{l}\text { Y1llik Maaş } \\
\text { (Sterlin) }\end{array}$ & Ek Gelir \\
\hline $\begin{array}{l}\text { Avusturya- } \\
\text { Macaristan }\end{array}$ & $\begin{array}{l}\text { Konsolos } \\
\text { yardımc1s1 }\end{array}$ & $\begin{array}{l}\text { Avust. Lloyd } \\
\text { kumpanyası } \\
\text { acentesi. Fakat } \\
\text { Ticaret } \\
\text { Yapmiyor }\end{array}$ & - & 100 & $\begin{array}{l}\text { Nakliye } \\
\text { komisyonu ve } \\
\text { ücretlerinden } \\
\text { y1llik ortalama } \\
\text { 150sterlin. }\end{array}$ \\
\hline Fransa & $\begin{array}{l}\text { Konsolos } \\
\text { yardımcis1 } \\
\text { vekili }\end{array}$ & $\begin{array}{l}\text { Ticaretle } \\
\text { uğraşıyor }\end{array}$ & $\begin{array}{l}- \\
1 \text { çalışan, } \\
\text { (konsolos } \\
\text { yardımcisı } \\
\text { vekili } \\
\text { tarafindan } \\
\text { tutulmuş) }\end{array}$ & $\begin{array}{l}- \\
50\end{array}$ & $\begin{array}{l}\text { Gemi ücretleri } \\
\text { ve } \\
\text { aidatlarından } \\
\text { yıllık ortalama } \\
\text { 100sterlin. }\end{array}$ \\
\hline Yunan & $\begin{array}{l}\text { Konsolos } \\
\text { yardımcis1 }\end{array}$ & $\begin{array}{l}\text { Ticaret } \\
\text { Yapmiyor } \\
\text { Ticari } \\
\text { Ticari }\end{array}$ & $\begin{array}{l}1 \text { kâtip } \\
1 \text { koruma }\end{array}$ & $\begin{array}{l}150 \\
65 \\
20\end{array}$ & $\begin{array}{l}\text { Konaklama } \\
\text { hizmeti }\end{array}$ \\
\hline İtalya & $\begin{array}{l}\text { Konsolos } \\
\text { vekili }\end{array}$ & Ticari & - & - & $\begin{array}{l}\text { Aidat ve } \\
\text { ücretlerin bir } \\
\text { k1smı }\end{array}$ \\
\hline
\end{tabular}

\footnotetext{
${ }^{48}$ Ali İbrahim Savaş, “Konsolos”, Diyanet Vakfi İslam Ansiklopedisi, Cilt: 26, Türkiye Diyanet Vakfi Yayınları, Ankara 2002, s. 178- 179 .

${ }^{49}$ Uygur Kocabaşoğlu, Majestelerinin Konsolosları, İletişim Yayınları, İstanbul 2004, s. 16.

${ }^{50}$ Rona Aybay, Tarih ve Hukuk Açısından Konsolosluk, Türkiye İş Bankası Kültür Yayınları, İstanbul 2009, s. 15.

${ }^{51}$ U. Kocabaşoğlu, a. g. e., s. 16.

52 Pars Tuğlacı, Osmanlı Şehirleri Tarihi, Milliyet Yayınları, İstanbul 1985, s. 347.

${ }^{53}$ BOA, I. HR, 119/5824, Tarih: 15 Cemaziyelahir 1271 ( 5 Mart 1855).

${ }^{54}$ Parliamentary Papers, Reports relative to British Consular Estalishments: 1858\&1871, Part III., s. 95- 96.
} 
1871 yılında Golos'ta Avusturya- Macaristan, Fransa, Yunan ve İtalya'ya ait konsolosluk kuruluşları bulunmaktaydı. Bu konsolosluklarda konsolos yardımcısı, konsolos yardımcısı vekili ve konsolos vekili görev yapıyordu. ${ }^{55}$

Yeni kurulan bu konsolosluklar Osmanlı Devleti'nin içişlerine karışmanın bir aracı olarak da kullanılmışlardır. Osmanlı Devleti'nin zayıf olduğu dönemlerde yetkilerini kötüye kullanmışlardır. ${ }^{56}$ Örneğin, Golos'ta Osmanlı tebaası ile yabancılar arasında yaralanma gibi olaylar vuku bulmuştur. Osmanlı Devleti'nde böyle bir olay yaşandığında yabancılar mensup olduğu konsolos tercümanı ile birlikte çağrılarak sorgulanmaktaydı. Bu tahkikat neticesinde gerekli ceza hükmü düzenlenmektedir. Ancak Golos'ta suç işleyen yabancılar bu ceza kanununa göre hapsedilirken mensubu oldukları konsolos vekilleri ceza kanununun uygulanmasına karş1 çıkmışlardır. Konsoloslar suçu sabit olan yabancıların kendi konsolosluk hapishanelerinde cezalandırılabileceklerini ifade etmişlerdir. Bâb-1 Âlî ise her devlette kanunların hükmünün uygulandığını ifade ederek yabancılar İstanbul'da suç işlediklerinde sefaret tercümanlarının nezaretinde sorgulanıp gerekli cezayı almalarını istemiştir. Dolayısıyla Golos'ta suç işleyenler konsolosların görevlendireceği tercümanların yönetiminde sorgulanıp cezasının verilmesi istenmiştir. Eğer konsoloslar buna da karşı çıkarsa durum tekrar Bâb-1 Âlî’de görüşülecektir. ${ }^{57}$ Osmanlı Devleti yabancı devletlerin konsoloslukları aracılığıyla içişlerine karışmalarına son vermek amacıyla çeşitli girişimlerde bulunmuş olsa da sonuç alınamamıştır. ${ }^{58}$

Tablo 5. 1858- 1871 Yıllarında Golos 'ta İngiliz Başkonsolosluğundaki Görevliler ${ }^{59}$

1858

\begin{tabular}{|c|c|c|c|c|c|}
\hline İsim & Statüsü & $\begin{array}{l}\text { Ticari } \\
\text { Konumu }\end{array}$ & $\begin{array}{l}\text { Yıllık Maaş } \\
\text { (Sterlin) }\end{array}$ & Ödenek & Hizme \\
\hline Robert Stuart & $\begin{array}{l}\text { Konsolos } \\
\text { Yardımcis1 }\end{array}$ & $\begin{array}{l}\text { İzni var } \\
\text { ama ticaret } \\
\text { yapmadı }\end{array}$ & 150 & $\begin{array}{l}\text { Konsolosluk } \\
\text { Ücreti }\end{array}$ & $1 \mathrm{y} 11$ \\
\hline \multirow[t]{2}{*}{ A. Dato } & $\begin{array}{l}\text { Geçici } \\
\text { Tercüman }\end{array}$ & Ticaret Dış1 & - & - & - \\
\hline & & & 1871 & & \\
\hline Henry Suter & $\begin{array}{l}\text { Konsolos } \\
\text { Yardımcis1 }\end{array}$ & $\begin{array}{l}\text { Ticaret } \\
\text { yapiyor }\end{array}$ & $\begin{array}{l}\text { Larissa'ya } \\
\text { ek olarak } 50\end{array}$ & $\begin{array}{l}\text { Konsolosluk } \\
\text { ücreti }\end{array}$ & $10 \mathrm{y} 1 \mathrm{l}$ \\
\hline D.Abramnel & Tercüman & $\begin{array}{l}\text { Ticaret } \\
\text { yapiyor }\end{array}$ & - & Y1llık ikramiye & $10 \mathrm{y} 1 \mathrm{l}$ \\
\hline ArnaontMallus & Bekçi & $\begin{array}{l}\text { Ticaret } \\
\text { yapmiyor }\end{array}$ & 15 & & $10 \mathrm{y} 11$ \\
\hline
\end{tabular}

\footnotetext{
${ }^{55}$ Parliamentary Papers, , Reports relative to British Consular Estalishments: 1858\&1871, Part III., s. 95- 96.

${ }^{56}$ R. Aybay, a. g. e., s. 27.

${ }^{57}$ BOA, HR. MKT, 328/79, Tarih: 19 Şaban 1276 (12 Mart 1860).

${ }^{58}$ R. Aybay, a.g. e., s. 389.

${ }^{59}$ Parliamentary Papers, Reports relative to British Consular Estalishments: 1858\&1871, Part III., s. 97.
} 
1858- 1871 yıllarında Golos'ta İngiliz Başkonsolosluğunda konsolos yardımcısı, geçici tercüman, tercüman ve bekçi görev yapmaktayd1. ${ }^{60}$

\section{3. Eşkıyalık Hareketleri}

Eşkıya, sözlükte "bedbaht, talihsiz; günahkâr, asi" gibi anlamlarına gelmekte olup şaki kelimesinin çoğuludur. Fakat Türkçe'de "yol kesen” manasına gelen katı'u't-tarîk "haydut, harami" anlamına gelen muhârib kelimelerinin karşılığı olarak kullanılmaktadır. ${ }^{61}$

Eşkıyalık genelde silahla yahut başka bir şekilde zor kullanarak yol kesip baskın yaparak mala ve cana tecavüz, kamu düzeni ve asayişi ihlal olarak tanımlanmaktadır. Eşkıyalığı ona yakın olan "bağy"dan ayıran fark ise mevcut siyasi iktidara karşı başkaldırı amacı bulunmamasıdır. ${ }^{62}$

Tarihin her döneminde devletlerin temel problemlerinden birisi iç güvenlik meselesidir. Osmanlı Devleti'nde de zaman zaman asayiş sorunları ortaya çıkmıştır. ${ }^{63} \mathrm{Bu}$ sorunların başında devleti zor durumda bırakan eşkıyalık olayları önemli rol oynamaktadır. Devlet otoritesinin zayıflaması ve bunun yanında yasaların artık uygulanmasında yaşanan zorluklar sonucunda haksızlıklar ortaya çıkmıştır. Aynı zamanda toprak sisteminde meydana gelen değişiklikler, toprak sistemindeki adaletsizlik, memurların halka kötü muamele etmesi gibi durumlar eşkıyalık olaylarını meydana getirmiştir. Yani eşkıyalığın kaynağı sosyal ve ekonomik sebeplerdir. Özellikle hayat standartlarındaki düşüş ve ekonomik kriz eşkıyalık hareketlerini yaygınlaştırmıştır. ${ }^{64}$

Osmanlı Devleti'nde eşkıya liderleri genellikle devlet görevlisi, tımar sahibi veya yüksek rütbeli askeri idarecilerdir. Bunlar daima devletin en zayıf olduğu zamanlarda, özellikle de savaş dönemlerinde ortaya çıkmıştır. ${ }^{65}$ Çoğu zaman bu eşkıyalık hareketleri devlete karşı değil halka yönelik olmuştur. Eşkıyalar adam yaralama, öldürme, hırsılık, yol kesme gibi eylemlerle toplumun güvenliğini bozmuşlardır. Ayrıca insanların mallarını yağmalayarak eşya ve hayvanlarını çalmışlar, tarım ve ticaretin sekteye uğramasına neden olmuşlardır. Eşkıyalık olayları halkın huzurunu bozmakla birlikte devlete ait gelirlerin azalmasına da yol açmıştır. ${ }^{66}$

19. yüzyılda Osmanlı Devleti'nin artık zayıflamaya başlaması, yabancı güçlerin kışkırtmaları ve milliyetçilik akımının etkisi ile ülkenin pek çok yerinde düzeni bozan olaylar çıkmıştır. Yunanistan'daki eşkıyalık faaliyetleri Osmanlı idaresi zamanında etkili olmaya başlamıştır. Osmanlılar tarafından Martolos Teşkilatı'nın kurulmasıyla bu hareketler giderilmek istenmiştir. Ancak bu teşkilatın üyeleri de fırsat buldukça eşkıyalık yapmaya kalkışmışlardır. Hatta 1821 Yunan isyanında da etkili bir şekilde yer almışlardır. Yunanistan, bağımsızlığından hemen önce Tırhala sancağında halkın huzurunu bozmak için eşkıyalık faaliyetlerini desteklemiştir. ${ }^{67}$ Sancağın genelinde eşkıyalık hareketleri etkili olmuştur. 1837 yılında Golos henüz nahiye

\footnotetext{
${ }^{60}$ Parliamentary Papers, Reports relative to British Consular Estalishments: 1858\&1871, Part III., s. 97.

${ }^{61}$ Ali Bardakoğlu, "Eşkıyalık”, Diyanet İslam Ansiklopedisi, Cilt: 11, Türkiye Diyanet Vakfı Yayınları, İstanbul 1995, s. 463.

62 Volkan Ertürk, "XVI. Yüzyılın İkinci Yarısında Vize Sancağında Eşkıyalık Hareketleri (1553- 1574)”, Çanakkale Araştırmaları Türk Yıllığ, 12, 2012, s. 98.

${ }^{63}$ Şaban Bayrak, XVIII. Yüzyılın İlk Yarısında Anadolu'da Eşkıyalık Olayları, Yayımlanmamış Yüksek Lisans Tezi, İnönü Üniversitesi Sosyal Bilimler Enstitüsü, Malatya 1998, s. 1.

${ }^{64}$ Ali Rıza Soyucak, Konya ve Çevresinde Eşklyalık Hareketleri (1640- 1675), Yayımlanmamış Yüksek Lisans Tezi, Selçuk Üniversitesi, Sosyal Bilimler Enstitüsü, Konya 1997; Nazmiye taş, 19. Yüzyılın İkinci Yarısında Çukurova Bölgesinde Eşklyalık Faaliyetleri, Yayımlanmamış Yüksek Lisans Tezi, Kafkas Üniversitesi, Sosyal Bilimler Enstitüsü, Kars 2015, s. 6.

${ }^{65}$ Mücteba İlgürel, “Osmanlılarda Eşkıyalık Hareketleri”, Diyanet İslam Ansiklopedisi, cilt: 11, Türkiye Diyanet Vakfı İslam Ansiklopedisi, İstanbul 1995, s. 467.

${ }^{66}$ Selda Öztürk, Mühimme Defteri'nde Bolu Sancağı ve Bolu'da Eşkıyalık, Yayımlanmamış Yüksek Lisans Tezi, Abant İzzet Baysal Üniversitesi, Sosyal Bilimler Enstitüsü, Bolu 2010, s. 91.

${ }^{67}$ B. Akyay, a.g.e., s.93; F. Çiftçioğlu, a.g.t., 258.
} 
konumunda iken eşkıyalık faaliyetleri görülmeye başlamıştır. Golos’taki eşkıyalar hem Osmanlı hem de Yunan gemileri tarafından abluka altına alınmıştır. Ancak eşkıyalar gemiye binerek Yunanistan'ın Yeniköy karşısındaki adaya kaçmışlardır. Yunanlıların bu eşkıyaları tutuklamayarak gizlice kaçıracakları düşünüldüğünden gerekli tedbirlerin alınması ve durumun Yunan elçiliğine bildirilmesi istenmiştir. ${ }^{68}$

Osmanlı Devleti eşkıyalık hareketlerinin önüne geçmek için gerekli bütün tedbirleri almaya çalışmıştır. 1848 yılında Golos'a gelen on bir eşkıyadan sekizi yakalanmış olup üçü kaçmıştır. Golos Kaymakamı bölgede bundan başka olayın olmadığı, kazanın eşkıyadan kurtulduğu yönünde malumat vermiştir. ${ }^{69}$

Yunan eşkıyaları Osmanlı Devleti sınırlarını tecavüz için sürekli fırsat kollamışlardır. Osmanlı Devleti'nin Kırım Savaşı'na girmesiyle birlikte aradıkları fırsatı yakalamışlardır. Osmanlı Devleti Yunan eşkıyalarının faaliyetlerine karşı gerekli tedbirleri alarak bölgedeki güvenliği artırmıştır. Güvenliğin sağlanması konusunda Ömer Paşa'nın yeterli olmadığı anlaşılmış bunun üzerine bölgeye sabık Hariciye Nazırı Fuat Efendi görevlendirilmiştir. Devlet aynı zamanda bölgedeki asker ve malzeme sevkine de büyük önem vermiştir. Hazırlıkların ardından askerlerin Golos İskelesi'ne çıkartılmasına karar verilmiştir. Ayrıca Golos İskelesi'nden gelip geçenlerin güvenliğinin sağlanarak orada bulunan eşkıyaların yakalanması için Tırhala Meclisi tarafından bir kıta geminin gönderilmesi istenmiştir. ${ }^{70}$

1853 yılı sonlarında Golos'un Milas köyünde on beş eşkıya gündüz vakti köy sakinlerinden Dimo nam-1 Nikogir'i yakalayarak ailesine eziyet edip iki kişiyi öldürmüş ve üç yüz elli bin kuruş akçesini almıştır. Bu olaydan yirmi gün sonra on iki haydut tekrar köye gelerek reayadan iki kişiyi yaralamıştır. Bu eşkıyalar tekrar Dimo adlı kişinin evine girerek yüz yirmi bin kuruş parasını ve eşyalarını alarak kaçmıştır. Golos ahalisine zarar veren bu eşkıyaların bir an evvel yakalanması için ilgili yerlere gerekli yazılar gönderilmiştir. Ahalinin gasp edilen eşyalarının geri verilerek bir daha böyle bir olayın yaşanmaması için Sadaret tarafından dikkatli olunması gerektiği bildirilmiştir. ${ }^{71}$ Ancak, Golos'taki bu eşkıyalık hareketleri halkın huzurunu kaçırmaya devam etmiş̧ir. Eşkıyalar Golos halkını kendilerine katılmaları için zorlamaya başlamış, kendilerine katılmayan Osmanlı tebaasının mağazalarını yağmalamış, bazılarını ise yollarda tutarak öldürmüşlerdir. Hatta kaza halkının evlerini ve kiliselerini bile yakmışlardır. Bu durum ailelerin de evlerini terk edip civar köylere kaçmalarına yol açmıştır. Golos halkı ise bu eşkıyalara katılmayarak devlete bağll1ıklarını her zaman dile getirmişlerdir. ${ }^{72}$

Osmanlı Devleti'nin aldığı tüm tedbirlere rağmen eşkıyalık faaliyetlerinin önüne geçilememiştir. Golos kazasından bu konuyla ilgili şikâyetler gelmeye devam etmiştir. Golos Kapı Kethüdası'na iki kişi mektup göndermiştir. Memleketlerinde Dölyo namlı eşkıyanın pek çok insanı katlettiği, ticareti sekteye uğrattı̆̆ı, yol kestiğinden dolayı köylüleri tedirgin ettiği bildirilmiştir. Bu konu hakkında kendi hükümetlerine de bilgi verilmesini istemişlerdir. Hatta Dölyo adlı bu kişi Dömeke taraflarını da ele geçirerek bir kişiyi öldürmüştür. Artık bu tedirginliğin ortadan kaldırılması istenmiştir. ${ }^{73}$

Golos'un Agraf nahiyesindeki kulelerin inşasına memur olarak İbrahim Efendi gönderilmiştir. İbrahim Efendi yanına aldığı iki tane yardımcısı ile yolda gittiği sırada eşkıyalar tarafından alıkonulmuştur. Haberi alan Binbaşı Ferhat Efendi, İbrahim Efendi ve yanındakilerin sağ

\footnotetext{
${ }^{68}$ BOA, HAT, 1315/52066, Tarih: 14 Saferi 1253 (20 May1s 1837).

${ }^{69}$ F. Çiftçioğlu, a. g. t., s. 259.

${ }^{70}$ F. Çiftçioğlu, a. g. t., s. 262.

${ }^{71}$ F. Çiftçioğlu, a.g.t., s. 263.

${ }^{72}$ BOA, $\dot{I}$. HR, 110/5379, Tarih: 14 Şaban 1270 (12 Mayıs 1854).

${ }^{73}$ BOA, HR. TO, 507/30, Tarih: 6 Zilhicce 1280 ( 13 Mayis 1864).
} 
kurtarılması için çaba sarf etmiştir. Eşkıya ise İbrahim Efendi ve yanındakileri bırakmak için üç bin lira para talep etmiştir. ${ }^{74}$

Osmanlı ve Yunan sınırından geçen eşkıyaların halka olan zulümleri gittikçe artmaktadır. Devlet, sınır boyunca görevli olan askerlerin gerekli tedbirleri alarak eşkıyalığın başka bölgelere yayılmamasını istemektedir. ${ }^{75}$ Bundan dolayı Yunan hududunda dolaşmakta olan eşkıyaların ortadan kaldırılması için Golos'a iki tabur asker gönderilmiştir. ${ }^{76} 1857$ yılında Golos kazasında tek tek gezmekte olan eşkıyalar yakalanarak Tırhala'ya gönderilmiş̧ir. Durum Tırhala Kaymakamı Hasan Paşa tarafından Yanya Valisi'ne bildirilmiştir. ${ }^{77}$

Rumeli Ordusu Müşiri Kaymakam Abdi Paşa yapılan mağazaların yerlerini kontrol etmek için Golos'a gitmiştir. Bu sırada hudut komiseri Mösyö Joto da oraya gelmiştir. Abdi Paşa ile Mösyö Joto bir araya gelerek oradaki eşkıyanın durumunu görüşmüşlerdir. Şemo namlı bir eşkıya Belbonlu Çiftliği'nde verdiği zarardan dolayı üzerine gelen Osmanlı askerinden kaçarak Yunanistan'a gitmiştir. Oradan da yanına otuz tane adam alarak tekrardan Osmanlı topraklarına saldırdığ1 söylenmiştir. Fakat hudut komiseri Joto kendisi ile yapılan görüşmede bunun doğru olmadığını eşkıyanın yanına aldığı adamların silahlarının bulunmadığını söylemiştir. Ayrıca eşkıyanın yakalanması için yanına dört yüz adam alarak gerekeni yapacağını belirtmiştir. Şemo namlı haydut en son Golos'ta sıkıştırılmıştır. Durum Tırhala Valisi İsmail Paşa tarafından bildirilmiştir. $^{78}$

Eşkıyalık faaliyetlerini yürütenler arasında devletin resmi görevlileri de bulunmaktadır. Görevleri hükümet işlerini yürütüp halkı korumak olan bu kişiler devlet otoritesinin zayıfladığı dönemlerde usulsüz hareket sergilemişlerdir. Bunların en başında ise rüşvet gelmekteydi. ${ }^{79} 1856$ yılında Golos kazasının köylerinde kocabaşılar halka zulmetmişlerdir. Bunun üzerine kocabaşılı̆̆ın kaldırılarak Tanzimat reformu çerçevesinde her köye muhbirler tayin edilmesi kararı alınmıştır. Bu değişiklikteki amaç ise halkı hoşnut etmektir. Osmanlı idaresi Müslim ve Gayrimüslim tebaasının haksızlığa ve zulme uğramasını kabul etmediği gibi memurlarında kendilerine verilen vazifeye uygun hareket etmelerini istemektedir. ${ }^{80}$ Kocabaşıların halka yaptıkları zulüm olarak adlandırılsa da resmi görevlilerin davranışları zulüm ile sınırlı kalmamıştır. Halkın mallarını yağmalayarak adam öldürme, yaralama gibi eşkıyalık hareketlerinde bulunmuşlardır. ${ }^{81}$

Golos kazası ve civarında eşkıyalar halkı oldukça zarara uğratmışlardır. Eşkıyalar halkın mağazalarını telef etmiş̧lerdir. Kaymakamın bütün gayretlerine rağmen eşkıyalık hareketleri önlenememiştir. Buna rağmen eşkıyadan büyük zarar gören halk devlete olan bağlılıklarından taviz vermediklerini bildirmiştir. ${ }^{82}$

\section{4. Íbadethaneler ve Mezarlıklar}

Farklı etnik grupları bünyesinde bulunduran Osmanlı Devleti içinde Müslüman olmayan topluluklar ayrı bir önem taşımıştır. Geniş topraklara sahip olan Osmanlı İmparatorluğu yönetimi

\footnotetext{
${ }^{74}$ BOA, A. MKT. MHM, 365/95, Tarih: 2 Cemaziyelevvel 1280( 12 Eylül 1866).

${ }^{75}$ BOA, A. MKT. MHM, 305/53, Tarih: 18 Muharrem 1280 (2 Temmuz 1863).

${ }^{76}$ BOA, A. MKT. MHM, 307/31 Tarih: 22 Saferi 1281 ( 27 Temmuz 1864).

${ }^{77}$ BOA, HR. MKT, 168/30, Tarih: 28 Rebiyülevvel 1273 ( 26 Kasım 1856).

${ }^{78}$ BOA, A. MKT. MHM, 261/ 90, Tarih: 8 Şaban 1279 ( 29 Ocak 1869).

${ }^{79}$ A. R. Soyucak, a.g e., s.42.

${ }^{80}$ BOA, A. MKT. MHM, 84/49, Tarih: 12 Cemaziyelahir 1272 (19 Şubat 1856).

${ }^{81}$ Ş. Bayrak, a. g. e., s. 15.

82 BOA, A. MKT. MHM, 88/24, Tarih: 27 Muharrem 1289 ( 6 Nisan 1872)
} 
altında Müslüman ve Müslüman olmayan topluluklar uzun bir süre huzur içerisinde birlikte yaşamışlardır. ${ }^{83}$

Osmanlı yönetimi altında bulunan bütün topluluklar millet sistemi adı altında idare edilmiştir. $\mathrm{Bu}$ sistem, farklı inançlara sahip topluluklara kendi inançları içinde özgürce yaşama hakk1 sağlamıştır. Devlet, topraklarında yaşayan tebaaya her zaman adaletli davranmıştır. Hiçbir şekilde gayrimüslim tebaayı İslamlaştırmak gibi bir çaba içerisine girmemiştir. Osmanlı Devleti'nin fethedilen bir yerdeki en büyük kiliseyi camiye çevirme hakkı vardı. Onun dışında hiçbir kiliseye dokunulmazdı. Ancak, şehir kendi iradesi ile teslim olmuşsa kiliselere asla dokunulmamıştır. ${ }^{84}$

1856 yılında Islahat Fermanı ile birlikte din ve mezhep özgürlüğü sağlanmıştır. Böylece okul, kilise vb. tamiri ve yeniden inşası yapılabilecektir. ${ }^{85}$ Bu bağlamda Osmanlı topraklarında farklı inanca sahip kişiler devletten ibadet edebilecekleri bir yer talep edebilmişlerdir. Örneğin, 1868 yılında Golos'un Vizici karyesinde Rum milletinin kiliseleri olmadığından Meryem Ana adında bir kilise yaptırmak için izin istemişlerdi. Bab-1 Ali'den gelen cevaba göre köyün gerçekten kiliseye ihtiyacının olup olmadığı, kilise yapılacak yerin kamu arazisi mi vakıf arazisi mi yoksa şahsi bir arazi mi buna bakılması istenmiştir. Ayrıca bu kilise yeri kalenin güvenliğini tehlikeye düşürecek yerde mi yapılacak bunların incelenmesi gerektiği bildirilmiştir. Yapılan araştırmalar sonucunda bu kilisenin yapılacağı yer Rogayani ve Anağtos çocuklarının mülk bahçeleri olduğu ve çocukların yerlerini kendi istekleri ile verdiği bildirilmiştir. İnşa edilecek kilisenin ne kaleye ne de bir başkasına herhangi bir zararının olmadığı anlaşılmıştır. Bu kilise için yer veren çocuklar ise; Rogayani 27 yaşında oğlu Konstanti ve Yani ile 23 yaşında Dimitri, 29 yaşında Ketrin, 17 yaşında Arni ve Yani Anağostos, 23 yaşında Yorgi, 21 yaşında Nikos ve 17 yaşında Dimitri adında kimselerdir. ${ }^{86} 1870$ 'lerin başında yine Rum milleti tarafından bazı yerlerde kilise yapılması için talepte bulunulmuştur. Golos'ta da Rumlar ibadet edecek mabetleri bulunmadığından kilise inşası için dilekçe göndermişlerdir. ${ }^{87}$ Golos'ta Yeni Mahalle'de bir kilisenin inşası iyi olacağından dolayı kilise yaptırılması uygun görülmüştür. ${ }^{88}$ Hatta Golos'ta bir Hristiyan kilisesi için izin verildiğinden dolayı İngiltere Konsolosu Mösyö Blani tarafından teşekkür mektubu yazılmıştır. ${ }^{89}$

Golos'ta cumartesi günleri halk tarafindan pazar kurulmaktadır. Yahudilerin kutsal günleri cumartesi olduğu için bundan dolayı Hahambaşı pazarın başka bir güne alınması için dilekçe vermiştir. Durum Meclis-i Vâlâ'da görüşülerek halkın ortak belirleyeceği bir güne pazar kurulması Tırhala mutasarrıflığına bildirilmiştir. ${ }^{90}$

Tırhala sancağı dâhilinde bulunan Protestan milletinin mezarlığı olmadığı yerlerde ölüler Ermeni milletinin mezarlığına defnedilmesinden dolayı dedikodu ve olay çıkmıştır. Protestan milletinin kendilerine has mezarlıkları olmadığı için, devletin boş arazilerinden yeterli miktarda ayrılmasıyla Protestan milleti için mezarlık tahsis edilmesi istenmiştir. Golos kazasında da bu durumun araştırılarak eğer Protestan milleti var ise orada da mezarlık yeri ayrılması istenmiştir. Ancak Golos'tan gelen yazıda burada İngilizler haricinde Protestan olmadığından böyle bir şeye gerek olmadığı ifade edilmiştir. ${ }^{91}$

\footnotetext{
${ }^{83}$ Yavuz Ercan, “Osmanlı Devleti'nde Müslüman Olmayan Topluluklar”, Osmanl, cilt: 4,Yeni Türkiye Yayınları, Ankara 1999, s. 197.

${ }^{84}$ Muammer Ulutürk, “ Osmanlı Devleti'nde Millet Sistemi”, Tefekkür Dergisi, 51, 2012, s. 1.

${ }^{85}$ Ufuk Gülsoy, "Islahat Fermanı", Diyanet Vakfi İslam Ansiklopedisi, Cilt: 19, Türkiye Diyanet Vakfi Yayınları, İstanbul 1999, s. 186.

${ }^{86}$ BOA, I. HR, 233/13734, Tarih: 9 Rebiyülahir 1285 (30 Temmuz 1868).

${ }^{87}$ BOA, $\dot{I} . H R, 257 / 15316$, Tarih: 12 Şaban 1289 ( 15 Ekim 1872).

${ }^{88}$ BOA, HR. MKT, 83/87, Tarih: 26 Zilkade 1270 (20 Ağustos 1854).

${ }^{89}$ BOA, HR. MKT, 91/99, Tarih: 4 Saferi 1271( 27 Ekim 1854).

${ }^{90}$ BOA, A. MKT. UM, 371/68, Tarih: 18 Rebiyülevvel 1276 (15 Ekim 1859).

${ }^{91}$ BOA, HR. MKT, 356/97, Tarih: 28 Cemaziyelevvel 1277 (12 Aralı 1860).
} 
Golos'ta mezarlıklar da kentsel planlama çerçevesinde elden geçirilmiştir. Tren istasyonunun arkasında bulunan Müslüman kabristanı özellikle Golos'un Yunanistan'a terk edilmesinden sonra bazı kişilerce uygunsuz farklı amaçlarla kullanılıyordu. Osmanlı şehbenderliği bu durumu önlemek adına kabristanın etrafina 150 lira karşılığına duvarlar ördürmüştür. ${ }^{92}$
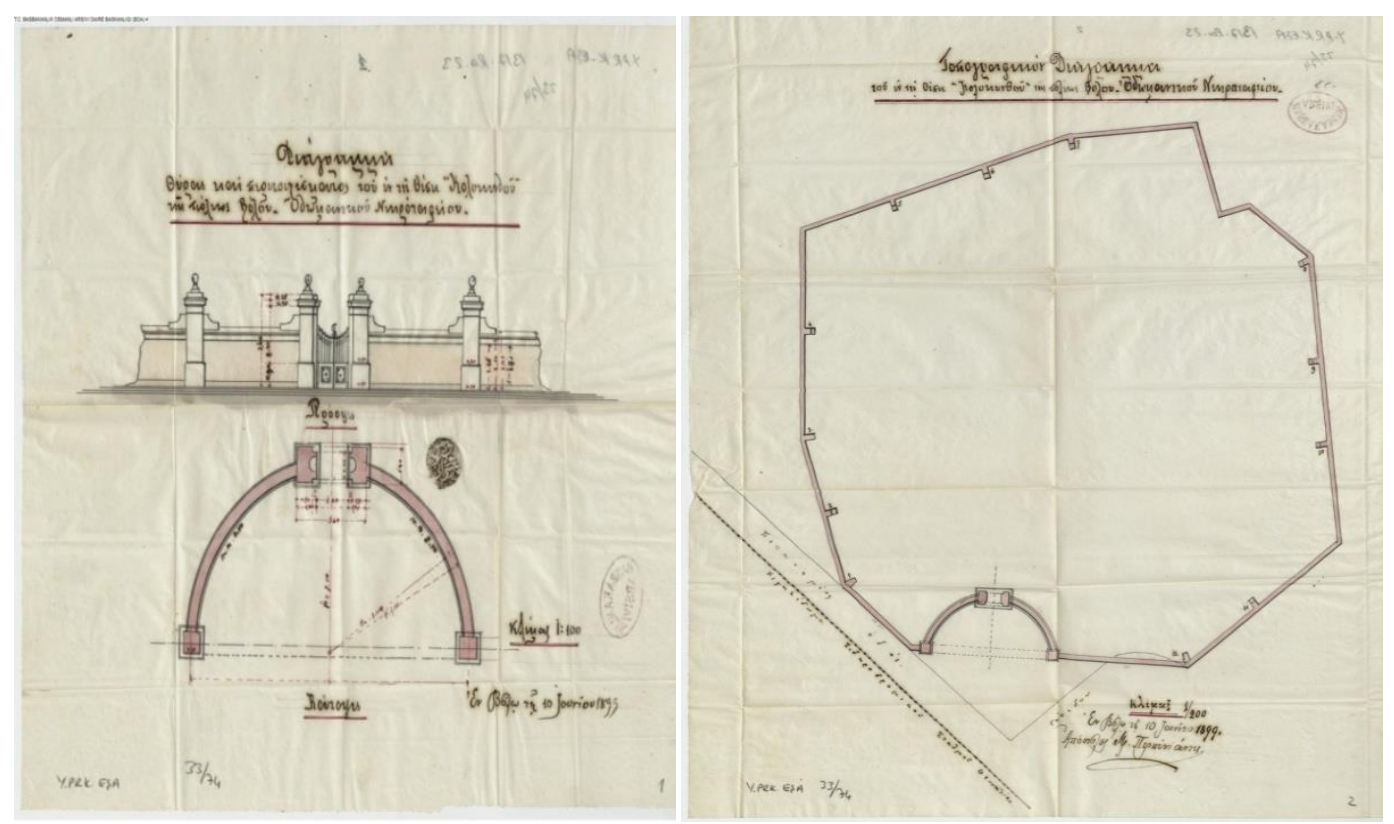

Harita 1. Golos'ta Tren İstasyonu Arkasında İslam Kabristan1 ${ }^{93}$

\section{5. Ĕ̈itim}

Osmanlı Devleti’nde eğitim ve öğretim faaliyetleri, 19. yüzyılın ortalarına kadar devletin görev alanının dışında kalmıştır. Eğitim faaliyetleri daha çok hayırsever kişilerin kurdukları vakıflar aracılığıyla yürütülmüştür. Ancak modernleşme çabaları çerçevesinde eğitim- öğretim işleri devlet görevi niteliği kazanmıştır. ${ }^{94}$

Osmanlı Devleti'nde eğitim alanındaki ilk yenilikler Batı tarzı askeri okulların açılmasıyla gerçekleşmiştir. Yenileşmelere öncelikle askeri eğitim ve öğretimden başlanmasının sebebi ise girişilen savaşlarda yenilgilerin artmasıdır. Osmanlı Devleti bu durumu Avrupa'da subay ve askerlerin iyi yetişmiş olmalarına, kendilerinin ise bu alanda geri kalmalarına bağlamıştır. ${ }^{95}$

Batı tarzında açılan askeri okulların yanı sıra medreselerinde varlığını idame ettirmesi eğitim alanında ikilik meydana getirmiştir. Bu durum sivil okulların da kurulmasıyla daha da belirginleşmiştir. Örneğin bir taraftan hukuk okulları Batı yasalarına göre hâkimler yetiştirirken, bir taraftan da Mekteb-i Kuzâd ve medreseler İslam fikhına göre hüküm verecek kadılar yetiştiriyordu. Yine eğitim dili Fransızca olan modern tıbbiye okullarının yanında geleneksel tıp eğitimi de verilmeye devam ediliyordu. ${ }^{96}$

Tanzimat'a kadar eğitim ve öğretim işleri Meclis-i Umur-1 Nafia ve Meclis-i Vâlâ-yı Ahkâm1 Adliye kuruluşları tarafından yürütülmüştür. ${ }^{97} 1839$ yılında Tanzimat Fermanı'nda eğitim ile

\footnotetext{
${ }^{92}$ BOA, YPRK. ESSA, 33/74, Tarih: 23 Cemaziyelevvel 1317 (29 Eylül 1899).

${ }^{93}$ BOA, YPRK. EŞA, 33/74, Tarih: 23 Rebiyülevvel 1317 ( 1 Ağustos 1899).

94 Ülker Akkutay, Enderun Mektebi, Gazi Üniversitesi Yayınları, Ankara 1984, s. 15- 16.

95 Yahya Akyüz, Türk Eğitim Tarihi, Pegem Akademi Yayınları, Ankara 2007, s. 144.

${ }^{96}$ Mehmet Okur, "Türkiye'de Milli ve Modern Bir Eğitim Sistemi Oluşturma Çabaları (1920-1928)", Çağdaş Türkiye Tarihi Araştırmaları Dergisi, 4 /11, 2005, s. 94.

${ }^{97}$ Yaşar Baytal, “ Tanzimat ve II. Abdülhamit Dönemi Eğitim Politikaları”, OTAM, 11/11, 2000, s. 26.
} 
ilgili herhangi bir kelime yoktu. ${ }^{98}$ Sultan Abdülmecid, Tanzimat Fermanı'nda eğitim meselesinin yer almayışını 1845 'te Meclis-i Vâlâ-yı Ahkâm-1 Adliye'de okuttuğu Hatt-1 Hümayun'da belirtmişti. Abdülmecid okuttuğu fermanda, yapılan çalışmaların askeri alanda sınırlı kaldığına dikkat çekmişti. Bu doğrultuda memleketin imar ve düzenleme işlerini yürütmek üzere çeşitli meclisler kurulurken, eğitim çalışmaları ile ilgilenecek olan geçici bir maarif meclisi oluşturuldu. Öğretimin Batı' daki gibi üç kademeli olması ve okulların yönetimini sağlamak üzere daimî bir Maarif Meclisi'ne ihtiyaç duyulmuştu. Bunun üzerine 1846'da ülkenin eğitim işleriyle uğraşacak Meclis-i Maarif-i Umûmiye kuruldu. ${ }^{99}$ Bu kurumlar eğitimde modernleşmenin ve örgütlenmeye gidişin ilk belirtileriydi. ${ }^{100}$

1857'de Maârif-i Umûmiye Nezareti'nin kurulmasıyla eğim ve öğretim devlet görevi ve kontrolü altına girmiştir. ${ }^{101}$ Eğitim ve öğretim alanındaki en kapsamlı reform hareketi 1869 yılında Maârif-i Umûmiye Nizamnamesi'nin yürürlüğe girmesiyle gerçekleşmiştir. Nizamnameye göre eğitim kurumları ilk, orta ve yüksek öğretim olmak üzere kademelendirilmiştir. ${ }^{102}$ Nizamname birçok yönden olduğu gibi maarif teşkilatı bakımından da yenilikler getirmiştir. Maarifin idaresi, teşkilat yapısı ve görevleri yasal bir hükme bağlanmıştır. ${ }^{103}$

19. yüzyılda ikinci yarısına gelindiğinde Golos kazasında da eğitime sancağın diğer kazalarına göre daha önem verildiği görülmekteydi. Bu durum okula devam eden öğrenci sayılarına yansımaktadır. ${ }^{104} 1871$ yılında Golos'ta okula devam eden öğrenci sayıs1 $3.622^{105}$, 1875 'te $3.120^{106}, 1876$ 'da 3.300 'dür. ${ }^{107}$

Golos ahalisi de eğitim konusunda oldukça duyarlı davranmıştır. Golos'ta rüştiye şeklinde bir mektebe ihtiyaç duyulmuştur. Bu doğrultuda kale içinde bulunan mektebin üst katı rüştiye, alt katı ise sıbyan mektebi olarak inşası bölgenin ileri gelenleri tarafından planlanmıştır. Bu iş için gerekli olan 13.108 kuruş masraf da ahalinin yardımları ile karşılanmıştır. Golos'taki mektep için bir muallimin tayini hususu Vilayet Meclisi tarafından İstanbul'a bildirilmiştir. Bu talep üzerine Maarif Meclisi muallimin gönderileceği cevabını vermişti. ${ }^{108}$

Kozmopolit bir yapıya sahip olan Golos'ta Rumlar çocuklarını kendi dillerinde eğitim verecek mektep bulunmadığı gerekçesiyle Atina'ya gönderiyordu. 1867 yılında Şura-yı Devlet'te tartışılan bu durum, Atina'ya giden çocukların Yunan kültürüne girdikleri gerekçesiyle eleştirilmiştir. Çözüm olarak Golos'ta gayrimüslimlerin çocukları için bir mektep yapılması gündeme getirilmiştir. Bu mektepte Arapça, Farsça, Rumca ve Fransızca derslerinin yanı sıra fen dersleri de verileceğinden çocukların Atina'ya gitmesine gerek kalmayacaktı. Yeni yapılan bu mektepteki hocaların yıllık masrafları ise 80.000 kuruştu. $\mathrm{Bu}$ paranın devlet tarafından karşılanması planlanmıştır. ${ }^{109}$

\section{6. Kültürel Miras}

Balkanlar, Asya ve Avrupa arasında bulunan bir kavşak noktasıdır. Dünya topraklarında bütün medeniyetlerin birbiriyle örtüştügü bir yerdir. Antik Yunan ve Roma, Bizans, Osmanlı ve Katolik

\footnotetext{
98 Y. Akyüz, a. g.e., s. 159.

99 Fatma Ürekli, "Tanzimat Dönemi Osmanlı Eğitim Sistemi ve Kurumları”, Manas Üniversitesi Sosyal Bilimler Dergisi, 3, 2002, s. 392.

100 M. Okur, a.g.m., s. 94.

${ }^{101}$ M.Okur, a.g.m., s. 94.

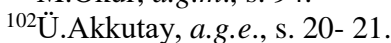

${ }^{103}$ Bayram Kodaman, Abdülhamit Devri Eğitim Sistemi, Türk Tarih Kurumu, Ankara 1991, s. 22.

${ }^{104}$ F. Çiftçioğlu, a.g.m., s. 2303.

${ }^{105}$ Yanya Vilayet Salnamesi, Def'a: 1, 1288 (1871), s. 114.

${ }^{106}$ Yanya Vilayet Salnamesi, Def'a: 2, 1292 (1875), s. 125.

${ }^{107}$ Yanya Vilayet Salnamesi, Def'a: 3, 1293 (1876), s. 188.

108 F. Çiftçioğlu, a.g.t, s. 245.

109 BOA, ŞD, 2085/21, Tarih: 19 Cemaziyelahir 1284 (18 Ekim 1867).
} 
Avrupa kültürleri burada bir araya gelmiştir. Bu kültürler zaman zaman birbiri ile kaynaşırken aynı zamanda da çatışmışlardır. ${ }^{10}$

Balkanlar coğrafi konumundan dolayı tarihin her döneminde ilgi odağ 1 olmuştur. Osmanlı Devleti, 14. yüzyılın ortalarından itibaren başlattığı Balkan fetih ve iskân hareketleriyle burada yaklaşık 550 yıl hüküm sürmüştür. 1354 yılında Süleyman Paşa komutasındaki Osmanlı kuvvetlerinin bölgeye girmesiyle Balkanların kapısı Türklere açılmış oldu. ${ }^{111}$

Osmanlı Devleti'nin 14. yüzyılın ikinci yarısında itibaren başlatmış olduğu fetih hareketleri Tesalya bölgesini de etkilemiştir. Doğu ovasının Gazi Evrenos Bey ve oğulları tarafindan fethedilmesinin ardından Anadolu'dan getirilen Türkler buraya yerleştirilmiş ve bölgede ilk İslami yapılar inşa edilmeye başlamıştır. ${ }^{112}$

19. yüzyılda Osmanlı Devleti topraklarını elinde tutma mücadelesi içine girmiştir. $\mathrm{Bu}$ dönemde Balkan milletleri bağımsızlık hareketine başlamışlardı. Balkan milletlerinin bu bağımsızlık mücadelelerine Avrupa devletleri de destek veriyordu. Nitekim 1821 y1lındaki Yunan isyanı da Avrupa devletleri tarafından desteklenmiştir. ${ }^{13}$ Yunan bağımsızlık hareketleri sonucunda 1830 yılında Yunanistan kurulmuştur. ${ }^{114}$ Bu tarihten itibaren Tesalya bölgesi, TürkYunan anlaşmazlığının sınır çatışmalarının yaşandığı bir bölge haline gelmiştir. Büyük güçlerin de araya girmesiyle birlikte bu anlaşmazlık uluslararası bir sorun haline gelmiştir. 1881'de yapılan İstanbul Anlaşmasıyla Tesalya bölgesi Yunanistan'a bırakılmıştır. Bu sırada bölgedeki birçok Osmanlı mirası da Yunanistan'a terk edilmiştir. Terk edilen miras Balkan coğrafyasının geneline bakıldığında önemli bir kısmını oluşturmaktaydı. Yunanistan konumu itibariyle diğer Balkan ülkelerinden farklılık göstermekteydi. Türk idaresine en erken katılan ve Türk nüfusunun en fazla bunduğu yerler arasında idi. Bu bağlamda sayı olarak en fazla Türk eseri bu ülkede inşa edilmiştir. ${ }^{115}$

Osmanlı hâkimiyeti zamanında Golos'ta mevcut Türk köprüsü ve bu köprübaşında büyük kubbeli bir camii vardı. Ayrıca Hüseyin Ağa, Haydar Bey, Sultan Süleyman camileri de bulunmaktaydı. 1866 yılına gelindiğinde Golos'a bir hükümet konağı yaptırılmıştır. ${ }^{116} 1871$ 'de Golos'ta 189 çeşme ile 53 köprü bulunmaktadır. ${ }^{117}$

Golos'un 1881 yılında Yunanistan'a bırakılmasıyla birlikte kazada bulunan bütün emlak ve hayratlar da devredilmiştir. Golos kazasında bulunan 15 arsa, 2 bağ, 14 bahçe, 6 dam, 1 değirmen, 48 dükkân, 1 firın, 2 hamam, 5 hane, 2 kahvehane, 1 kale, 2 mağaza, 1 nalbant dükkanı, 1 nısfı dükkan, 4 oda, 15 tarla, 4 tuz mağazası, 1 yağ değirmeni, 1 yağhane, 1 yonca bahçesi, 7 zeytinlik, 7 camii, 1 köşk, 8 mektep ve 6 mescit Yunanistan'a bırakılmıştır. ${ }^{118}$

Golos'ta bulunan Eski Cami, kale içinde yüksek bir tepede büyük taşlardan inşa edilmiştir. 1889 yılında Golos Kalesi'nin surları yıkıldıktan sonra camii rüzgâra açık hale gelmiştir. 1944'te camiinin minaresi kesilmiştir. 1955 y1lında meydana gelen deprem sonucunda hasar gören camii tamamen yıktırılmıştır.

\footnotetext{
110 Ali Çelebi, II. Abdülhamit Dönemi’nde Balkanlarla İlgili İstihbarat Raporları, Yayımlanmamış Yüksek Lisans Tezi, Ondokuz Mayıs Üniversitesi, Sosyal Bilimler Enstitüsü, Samsun 2018,s. 49.

${ }^{111}$ Caner Sancaktar, "Balkanlarda Osmanlı Hâkimiyeti ve Miras”, Ege Stratejik Araştırmalar Dergisi, 2/2, 2011, s. 29.

${ }_{112}$ Machiel Kiel, "Tesalya”, Diyanet Vakfi İslam Ansiklopedisi, Cilt: 40, Türkiye Diyanet Vakfı Yayınları, İstanbul 2011, s. 522.

113 İ. Serbestoğlu, a.g.m., s. 226.

${ }^{114}$ B. Akyay, a.g.t., s. 28.

${ }^{115}$ Ferdi Çiftçioğlu, Tırhala Sancağı'ndan Yunanistan'a Terk Edilen Osmanlı Miras1, Asia Minor Studies, 6/12, 2018, s. 74.

116 P. Tuğlac1, a.g.e., s. 347.

117 Yanya Vilayet Salnamesi, Def'a: 1, 1288 (1871), s. 113.

${ }^{118}$ F. Çifçtioğlu, a. g. t., s. 102.
} 


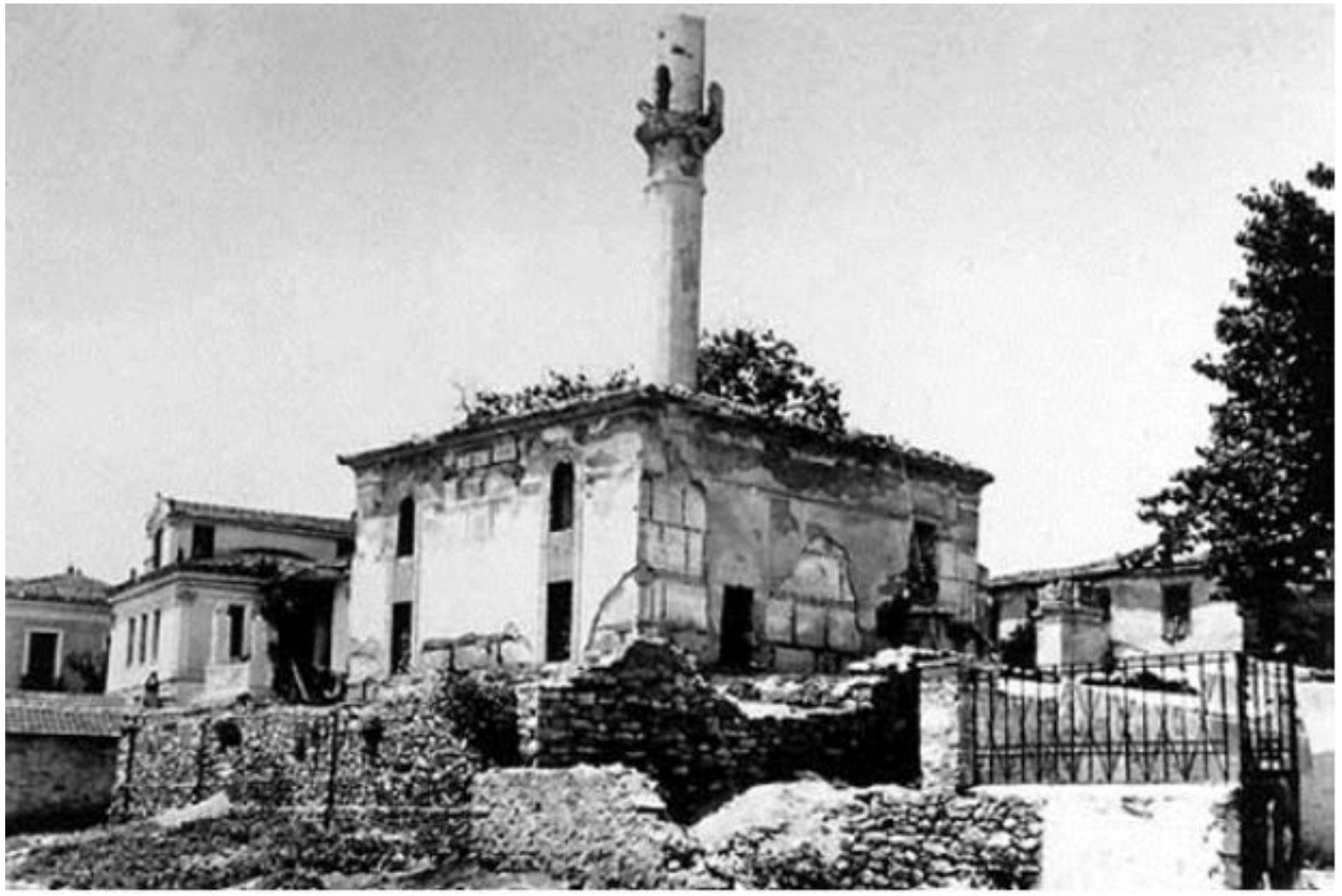

Fotoğraf. Golos Eski Camii ${ }^{119}$

\section{7. Doğal Afetler}

Toplumlar tarih boyunca sel, yangın deprem, çekirge istilası, salgın hastalıklar gibi afetler ile mücadele etmiştir. Bu olaylar insanların iradesi dışında gerçekleştiği için doğal afet olarak kabul edilmektedir. ${ }^{120}$

Doğal afetler toplumların sosyal kültürel ve ekonomik yapılarını önemli ölçüde etkilemektedir. Meydana geldikleri takdirde can ve mal kaybına neden olmaktadır. Özellikle salgın hastalıklar canlıların yaşamını doğrudan tehdit eden felaketlerdir. Sel, kuraklık, çekirge istilas1 gibi olaylar ise ürünlere zarar vermiştir. Yaşanan olumsuzluklar sonucunda insanlar vatanlarını terk etmek zorunda kalmıştır. Dolayısıyla yerleşim birimlerinde nüfus değiş̧ikliklerine neden olmuşlardır. ${ }^{121}$

\section{1. Çekirge İstilaları}

Çekirge istilaları, kıtlıklar ve büyük facialara yol açtığından dolayı insanlığı doğrudan etkileyerek ülkeleri açlık tehlikesi ile karşı karşıya bırakmıştır. Zirai ürünlerde zarara yol açan bundan dolayı insan yaşamını olumsuz etkileyen ve bitki örtüsüne zarar veren haşere ve hayvan sayısındaki artış biyolojik kökenli doğal afet olarak adlandırılmaktadır. ${ }^{122}$

\footnotetext{
${ }^{119}$ Baki Sarısakal, “Golos Eski Camii” http://bakisarisakal.com/goloscamisi.pdf.

${ }^{120}$ Orhan Kılıç, “Osmanlı Devleti’nde Meydana Gelen Kıtlıklar”, Uluslararası Sosyal Araştırmalar Dergisi, 2/19, 2002, s. 718.; Abdulkadir Gül, “Osmanlı Devleti’nde Kuraklık ve Kıtlık”, Uluslararası Sosyal Araştırmalar Dergisi, 2/9, 2009, s. 144.

${ }^{121}$ F. Çiftçioğlu, a.g.t, s. 249.

${ }^{122}$ Hakan Asan, "Diyarbakır Vilayeti'nde Meydana Gelen Çekirge Afetleri (1886-1919)", History Studies, 9/4, 2017, s. 2.
} 
Çekirgeler, bol yağış alan, yumuşak alüvyonlu toprak ve çöl bölgelerinde hızlı bir şekilde çoğalmaktadır. Belirli bir yoğunluk kazandıktan sonra sürü halinde yaşamaya başlayan çekirgeler, sıcak rüzgârlar ile birlikte gündüzleri uzak mesafelere gidebilmektedir. Akşamları ise bir sürü halinde yere inerek metre kareye iki yüz çekirge düşmesiyle büyük bir yoğunluğa ulaşmaktadırlar. Bu kilometre karede iki yüz milyon çekirgeyi ifade etmektedir. ${ }^{123}$ 19. yüzyılda Osmanlı Devleti Çekirge afetleriyle mücadele etmek zorunda kalmıştır. Çekirge istilası 1850 yılında Golos kazasında da etkili olmuştur. Golos kazasında çekirge ile mücadelede seksen altı bin yüz yetmiş altı kuruş masraf çıkmıştır. Çekirgenin defi için gerekli bu meblağın yirmi beş bin kuruşu padişah tarafından verilmiştir. Geri kalan kısmının yarısı Golos mal sandığı tarafından diğer yarısı ise kaza halkı tarafindan karşılanmıştır. ${ }^{124}$

1858 yılına gelindiği zaman Golos mal sandığından çekirge toplanmasında seksen altı bin yüz doksan yedi kuruş açık ortaya çıkmıştır. Bu yedi yıllık bir faaliyetin sonucudur. Bu açıktan ne kadarının çekirge toplanmasına harcandığı ne kadarının kimlerin zimmetinde kaldığ 1 da belli değildir. Bu kadar harcama neredeyse Tırhala sancağının giderinden fazladır. Bunlar çekirge toplama parası olarak kayıtlara geçmiş ancak sadece yirmi beş bini harcanmıştır. Geri kalanın ise nereye harcandığı bilinmemektedir. O zamanın Golos Müdürü Daver Efendi hayatta olmadığg için gerçekler ortaya çıkartılamamıştır. Dolayısıyla yirmi beş binin haricindeki paranın yarısını hazine karşılayacak diğer yarısını da çiftçinin vergisine ilave edilerek bir defaya mahsus toplanmıştır. ${ }^{125}$

\subsection{Kolera Salgını}

Salgın hastalıklar, virüs, bakteri ve mikroplarla taşınmaktadır. Hastalık, hücre ve dokularda meydana gelen yapısal ve fonksiyonel değişiklikler sonucu oluşmaktadır. Hastalık sonucu sadece bireyin kendisi etkilenmez, aynı zamanda hastanın yakın çevresi hatta toplumun geneline etki edebilmektedir. Aslında hastalığın sadece biyolojik değil, psikolojik ve sosyal etkileri de bulunmaktadir. ${ }^{126}$

Salgın hastalıklar, eski devirlerden itibaren binlerce yıl insan hayatını etkilemiştir. İnsanların yaşadığı sağlıksız ortamlar, ekolojik dengenin bozulması, kıtlık, doğal afetler ile birlikte pek çok sebep sonucunda salgın hastalıklar ortaya çıkmıştır. ${ }^{127}$

İnsan sağlığını tehdit eden ve ölümcül olan hastalıklar bulaşıcı olmaları durumunda afet olarak kabul edilmektedir. Eski dönemlerde veba, çiçek, frengi, kolera, verem, sıtma ve cüzam gibi hastalıklar insan hayatını önemli ölçüde tehdit etmekteydi. ${ }^{128}$ Bulaşıcı olan bu hastalıklar geniş alanlara yayılarak bulundukları bölgedeki insanların büyük sıkıntılar yaşamasına sebep olmuştur. Özellikle ilkel tedavi yöntemlerinin kullanıldığı dönemlerde ne tür tedbirler alınması gerektiği bilinmediğinden hastalıkların daha geniş alanlara yayılmasına neden olmuştur. Salgın hastalıklar tedavi yöntemleri bulununcaya kadar toplu ölümlere yol açmıştır. Yüz binlerce insanın ölümüne neden olan salgın hastalıklar diğer doğal afetler arasında en etkileyici ve zarar verici olanlardır. ${ }^{129}$

\footnotetext{
${ }^{123}$ Selma Turhan Sarıköse, XIX. Yüzyılda Çukurova'da Doğal Afetler ve Salgın Hastalıklar, Yayımlanmamış Doktora Tezi, Selçuk Üniversitesi, Sosyal Bilimler Enstitüsü, Konya 2013, s. 31.

124 BOA, A.MKT. NZD,6/15, Tarih: 15 Cemaziyelahir 1266 (28 Nisan1850); BOA, A.MD, 17/58, Tarih: 21 Cemaziyelevvel 1266 ( 4 Nisan 1850).

${ }^{125}$ BOA, I. MVL, 393/17115, Tarih:7 Ramazan 1274 (21 Nisan 1858).

${ }^{126}$ S. Turhan Sarköse, a.g. t., s. 33.

${ }^{127}$ Orhan Kılıç, Eskiçağdan Yakınçağa Genel Hatlarıyla Dünyada ve Osmanlı Devleti’nde Salgın Hastalıklar, Fırat Üniversitesi Basımevi, Elazığ 2004, s. 12-12.

${ }^{128}$ O. Kılıç, a.g.e., s. 12-13.

${ }_{129}$ Mesut Aydın, 1808- 1839 Yılları Arasında Osmanlı Devleti’nde Doğal Afetler, Yayımlanmamış Yüksek Lisans Tezi, Sinop Üniversitesi, Sosyal Bilimler Enstitüsü, Sinop 2018, s. 47.
} 
19. yüzyılda Osmanlı Devleti'nin önemli sorunlarından birisi de salgın hastalıklar olmuştur. Osmanlı Devleti çok geniş topraklara sahip olmasından dolayı sürekli bu sıkıntılara maruz kalmıştır. Osmanlı toplumunda geleneksel tıp ve dinsel yaklaşımlar hâkim olduğu için hastalıkların önüne geçilememiştir. ${ }^{130}$

Büyük acılara, toplu ölümlere ve en fazla tahribata neden olan hastalıkların başında ise kolera ve veba salgını gelmiştir. Veba salgını 16. yüzyıldan 19. yüzyıla kadar Osmanlı topraklarında en fazla rastlanan bir hastalık olmuştur. 19. yüzyıl ortalarına doğru veba salgını Osmanlı topraklarını terk etmeye başlamıştır. Ancak, vebadan daha tehlikeli, daha hızlı ve öldürücü olan kolera salgını görülmeye başlamıştır. ${ }^{131}$ Kolera, insanlık tarihi boyunca toplu ölümlere sebep olan ve en fazla tahribata yol açan salgın hastalıklardan birisidir. 19. yüzyıldaki insan ölümlerinin en başında kolera hastalığ 1 gelmektedir. ${ }^{132}$

Çok çeşitli yollarla yayılabilen koleranın bulaşmasında kirli su kaynaklarının önemi büyüktür. Bu nedenle hastalığın gelişmesinde önemli bir noktada alt yapı yetersizliğidir. Özellikle kışla, hapishane, okul ve hastane gibi toplu ortamlar hastalığın salgın şeklinde ilerlemesine sebep olmaktadır. ${ }^{133}$ Nitekim ilk olarak nüfusun yoğun olduğu ve ticaretin geliştiği yerlerde daha sık görülmüş̧ür. ${ }^{134}$

19. yüzyıl ise kolera salgını için bir dönüm noktası olmuştur. Bu dönemde ticari faaliyetlerin artmasıyla birlikte ticaret yolları aracıllı̆ı ile tüm dünyaya yayılmıştır. Özellikle 19. yüzyılda ulaşımda yaşanan gelişmeler hastalığın hızlı bir şekilde diğer bölgelere yayılmasında etkili olmuştur. ${ }^{135}$ Hastalık Asya, Afrika ve Amerika olmak üzere neredeyse bütün dünyada etkili olmuş ve insanların ölümüne sebep olmuştur. ${ }^{136}$ Osmanlı Devleti'nde ise kolera hastalığı ilk kez 1822 y1lında görülmeye başlamıştır. ${ }^{137}$

Osmanlı Devlet'i koleranın yayılmasını engellemek için bazı tedbirler alma yoluna gitmiştir. Önceleri sadece hastaların veya hastalık çıkan bölgelerin tecrit edilmesi şeklinde basit önlemler alınmıştır. 19. yüzyılda daha modern uygulamalarla salgın önlenmeye çalışılmıştır. Bu önlemlerin başında karantina uygulaması gelmektedir. Karantina, salgın hastalıkların kitlesel ölümlere yol açtığ ilk dönemlerde özellikle liman şehirlerinde hastalık taşıyan gemilere ateş topları atarak limandan uzaklaştırılmasıyla gerçekleştirilmiştir. ${ }^{138}$

Hastalık, deniz ve kara ticaret yollarının kesişme noktasında bulunan Osmanlı topraklarında psikolojik, sosyal ve ekonomik olarak büyük zararlar vermiştir. ${ }^{139}$ Büyük tahribata yol açan kolera salgını Tırhala sancağının Golos kazasında da etkili olmuştur. 1855 yılında Golos kazasının bazı köy ve çiftliklerinde kolera hastalığından ölümler görülmüştür. Golos'taki Hristiyan, Müslüman ve Yahudi milletinden on bir kişi vefat etmiştir. Sadaret tarafindan hastalığın yayılmasını engellemek için karantina hekimi ve tabiplerin gerekli önlemleri almaları istenmiştir. Bunun üzerine karantina hekimi ve diğer tabipler salgının önlenmesi için bir takım teşebbüslerde

\footnotetext{
${ }^{130}$ Ferdi Çiftçioğlu, II. Abdülhamit Dönemi’nde İzmir'de Salgın Hastalıklar, Yayınlanmamış Yüksek Lisans Tezi Celal Bayar Üniversitesi, Sosyal Bilimler Enstitüsü, Manisa 2014, s. 7.

131 A. Gül, a.g.m., s. 242.

132 A. Gül, a.g.m., s. 242.

133 A. Gül, a.g.m., s. 241.

${ }^{134}$ Mesut Ayar, Osmanlı Devleti'nde Kolera Salgını: İstanbul Örneği (1892- 1895), Yayımlanmamış Doktora Tezi, Marmara Üniversitesi, Türkiyat Araştırmaları Enstitüsü, İstanbul 2005, s. 6.

${ }^{135}$ S. Turhan Sarıköse, a.g.t., s. 40- 41.

${ }^{136}$ A. Gül, a.g.m., s. 242.

${ }^{137}$ M. Ayar, a.g.t., s. 17.

138 Fatma Şimşek, "19. Yüzyılın İkinci Yarısında Osmanlı Liman Kentlerinde Karantina Uygulaması"; Berna Türkdoğan Armăgan Kitabı, Editör:Ş. Kantarcı-F. Şimşek, Sonçă̆ Yayınları, Ankara 2015, s. 399.; F. Çiftçioğlu, a.g.m.,s. 7

${ }^{139}$ M. Ayar, a.g.t., s. 17.
}

\section{5}

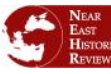


bulunmuşlardır. Bunların başında temizliğe dikkat edilmesi gelmektedir. Ayrıca alınıp yenilmesi yasak olan erzak ve meyvelerin satışına dikkat edilmiş hatta yasaklanmıştır. Golos'ta ölümler gerçekleşmiş olsa da alınacak tedbirler ile hastalığın yayılmasının önüne geçilebileceği düşünülmüştür. Golos’ta hastalık hafif yaşandığı için sadece temizliğe dikkat edilerek salgının önü alınmaya çalışılmıştır. ${ }^{140}$

1865 yılında Golos'taki hekim tarafindan koleradan ölen bir kişinin vefatından dolayı kazada salgın olduğu konsoloslara bildirilmiştir. Ancak yüz bin nüfuslu bir şehirde bu vaka haricinde herhangi bir olay yaşanmamıştır. Tırhala mutasarrıflı̆̆ ise hekimin ısrarı üzerine bu tavrının Yunan gemilerini karantina altına almak amacı taşıdığını düşünmektedir. Golos'taki bu karantina tabibi hakkında Tırhala mutasarrıfi'nın gönderdiği yazı sıhhiye meclisince müzakere edilmiştir. Birkaç adamın vefatından dolayı bunun bir salgın olarak kabul edilemeyeceği kararı alınmıştır. ${ }^{141}$

\section{Sonuç}

19. yüzyılda meydana gelen Sanayi Devrimi'nin ardından Avrupa, hammadde ve pazar arayışı içerisine girmiş̧ir. Osmanlı Devleti de bu süreçten fazlasıyla etkilenmiştir. Bunun nedeni ise, Osmanlı Devleti'nin yabancı devletlerle imzaladığı ticaret anlaşmalarıdır. Bu dönemde teknoloji alanındaki gelişmeler dünyada ticari ilişkilerin artmasında etkili olmuştur.

Ticaretin gelişmesiyle birlikte kentler önem kazanmaya başlamıştır. 19. yüzyılın ikinci yarısından itibaren Osmanlı kentleri modernleşmeye başlamıştır. Özellikle liman kentleri daima ön planda olmuşlardır.

Doğu Akdeniz Bölgesi'nde bir liman kenti olan Golos, 19. yüzyıl başlarına kadar henüz küçük bir yerleşim yeri iken bu tarihten sonra hızla gelişmeye başlamıştır. Bu gelişmede Tanzimat'ın etkilerinin yanı sıra bölgede ki halkın ihtiyaçları doğrultusundaki talepleri de etkili olmuştur.

19. yüzyıldan itibaren yaşanan ekonomik gelişmelere paralel olarak Golos'ta önemli bir nüfus artışı yaşanmıştır. Golos. Tırhala sancağının Yenişehir-i Fenar'dan sonra ki en fazla Müslüman nüfusun bulunduğu kazası olmuştur. Demografik alanda meydana gelen bu gelişmeler Golos'un bir liman kenti olarak sahip olduğu sosyal ve ekonomik çekim gücünden kaynaklanmaktaydı. Kazanın nüfusunun büyük bölümünü gayrimüslimler oluşturmaktadır. Golos kozmopolit bir yapıya sahip olup her millet kendi kültürünü devam ettirmiştir. Osmanlı Devleti Müslüman geleneklerini uygulamaya yönelik herhangi bir baskı yapmamıştır.

Golos'ta yaşanan gelişmeler 1881 yılında bölgenin elden çıkışına değin sürmüştür. Bu tarihten sonra kısa bir süre Osmanlı hâkimiyetinde kalan şehir 1897 Türk- Yunan Savaşı'ndan sonra tamamen Yunanistan'a bırakılmıştır.

${ }^{140}$ BOA, A. MKT. NZD, 158/98, Tarih:1 Zilhicce 1271 (15 Ağustos 1855); BOA, HR. MKT, 112/81, Tarih: 25 Şevval 1271(11 Temmuz 1855).

${ }^{141}$ BOA, A. MKT. MHM, 344/25, Tarih: 1 Cemaziyelahir 1282( 22 Ekim 1865). 


\section{KAYNAKÇA}

\section{ARŞIV VESIIKALARI}

\subsection{Cumhurbaşkanlığı Arşivleri Omsnalı Arşivi (BOA)}

BOA. A. MKT. MVL 83/5

BOA. A. MKT. MHM 365/95

BOA. A. MKT. MHM 305/53

BOA. A. MKT. MHM 307/31

BOA. A. MKT. MHM 261/90

BOA. A. MKT. MHM 841/49

BOA. A. MKT. MHM 88/24

BOA. A. MKT. NZD 6/15

BOA. A. MD $17 / 58$

BOA. A. MKT. NZD 158/98

BOA A. MKT. UM, 371/68

BOA. A. MKT. MHM 344/ 25

BOA. HR. MKT, 83/87

BOA. HR. MKT, 91/99

BOA. HR. MKT, 356/97

BOA. HR. MKT, 168/30

BOA. HR. TO, 507/30

BOA. HR. MKT 328/79

BOA. HAT 1315/52066

BOA. İ. HR, 119/5824

BOA. İ. HR, 110/5379

BOA. İ. HR, 233/13734

BOA. İ. HR, 257/15316

BOA. I. MVL, 993/17115

BOA. ŞD, 2085/21

BOA. YPRK. EŞA, 33/74

\subsection{YAYIMLANMIŞ BELGELER}

Paliamentary Papers, Reports relative to British Consular Establishments: 1858\&1871, Part III, 1871. 


\section{SALNAMELER}

Yanya Vilayet Salnamesi, Def'a: 1

Yanya Vilayet Salnamesi, Def'a: 2

Yanya Vilayet Salnamesi, Def'a: 3

\section{TETKIKK ESERLER}

Arslan, İbrahim, 19. Yüzyılda Balkanlarda Bir Liman Şehri: Kavala, History Studies Dergisi, 2 (3), 2010, s. 25-38.

Athanassiou, Evangelia \&Christodouou, Chatzipavlou, Thecity of volos in the network of meditterranean. cities. Museums in Motion, Symposium Proceeding, University of ThessalyPress, 2015.

Akyay, Bülent., Tesalya Meselesi (1881), Yayımlanmamış Yüksek Lisans Tezi, Ege Üniversitesi Sosyal Bilimler Enstitüsü, İzmir 2001.

Akşit, Bekir., XIX. Yüzyıl Ortasında Uluborlu Kazasının Nüfusu Yapısı, Yayımlanmamış Yüksek Lisans Tezi, Selçuk Üniversitesi, Sosyal Bilimler Enstitüsü, Konya 2016.

Aybay, Rona., Tarih ve Hukuk Açısından Konsolosluk, Türkiye İş Bankası Kültür Yayınları, İstanbul 2009.

168

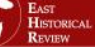

$10 / 2$

April

2020

Akkutay, Ülker, Enderun Mektebi, Gazi Üniversitesi Yayınları, Ankara 1984.

Akyüz, Yahya, Türk Eğitim Tarihi, Pegem Akademi Yayınları, Ankara 2007.

Ayar, Mesut, Osmanlı Devleti’nde Kolera Salgını: İstanbul Örneği (1892-1895), Yayımlanmamış Doktora Tezi, Marmara Üniversitesi, Türkiyat Araştırmaları Enstitüsü, İstanbul 2005.

Aydın, Mesut, 1808- 1839 Yılları Arasında Osmanlı Devleti'nde Doğal Afetler, Yayımlanmamış Yüksek Lisans Tezi, Sinop Üniversitesi, Sosyal Bilimler Enstitüsü, Sinop 2018.

Ballı, Ergül, "Modernleşme Çağında Karadeniz'de Bir Liman Kenti: Bartın”, ODÜ Sosyal Bilimler Araştırmalar Dergisi, 5 (12), 2015, s. 510- 541.

Bozkurt, Nebi, "Nüfus". Türkiye Diyanet Vakfi İslam Ansiklopedisi, C. 33, Türkiye Diyanet Vakfı Yayınları, İstanbul 2007, s. 293- 294.

Bardakoğlu, Ali, "Eşkıyalık”, Türkiye Diyanet Vakfi İslam Ansiklopedisi C.11,Türkiye Diyanet Vakfi Yayınları, İstanbul 1995, s. 463- 466.

Bayrak, Şaban, XVIII. Yüzyılın İlk Yarısında Anadolu'da Eşkıyalık Olayları, Yayımlanmamış Yüksek Lisans Tezi, İnönü Üniversitesi, Sosyal Bilimler Enstitüsü, Malatya 1998.

Baytal, Yaşar, “Tanzimat ve II. Abdülhamit Dönemi Eğitim Politikaları”, OTAM, 2000, 11 (11), s. 23- 32 .

Çelebi, Ali, II. Abdülhamit Dönemi'nde Balkanlarla İlgili İstihbarat Raporları, Yayımlanmamış Yüksek Lisans Tezi, Ondokuz Mayıs Üniversitesi Sosyal Bilimler Enstitüsü, Samsun 2018.

Çiftçioğlu, Ferdi, "XIX. Yüzyılda Osmanlı Devleti İçin Balkanlarda Stratejik Bir Liman Kenti: Golos", Journal of Social and Humanities Sciences Research, 5 (25), 2018, s. 2299- 2305.

Çiftçioğlu, Ferdi, XIX. Yüzyılda Tırhala Sancă̆ı (1821- 1881), Yayımlanmamış Doktora Tezi, Manisa Celal Bayar Üniversitesi, Sosyal Bilimler Enstitüsü, Manisa 2018. 
Çiftçioğlu, Ferdi, “Tırhala Sancă̆ı'ndan Yunanistan'a Terk Edilen Osmanlı Mirası”, Asia Minor Studies, 6 (12), 2018, s.72- 90.

Çiftçioğlu, Ferdi, II. Abdülhamit Dönemi İzmir'de Salgın Hastalıklar, Yayımlamamış Yüksek Lisans Tezi, Celal Bayar Üniversitesi, Sosyal Bilimler Enstitüsü, Manisa 2014.

Ercan, Yavuz, "Osmanlı Devleti'nde Müslüman Olmayan Topluluklar (Millet Sistemi)", Osmanl, C. 4, Yeni Türkiye Yayınları, İstanbul 1999, s. 197- 207.

Ertürk, Volkan, “XVI. Yüzyılın İkinci Yarısında Vize Sancağı'nda Eşkıyalık Hareketleri 15531574)", Çanakkale Araştırmaları Türk Yıllığ, 10 (12), 2012, s. 97- 107.

Erken, İlkay, Yanya Sancağının İdari Yapısı ve Yerleşim Birimleri (1867- 1913), Ondokuz Mayıs Üniversitesi, Sosyal Bilimler Enstitüsü, Yayımlanmamış Doktora Tezi, Samsun 2019.

Gül, Abdulkadir, "Osmanlı Devleti’nde Kuraklık ve Kıtlık”, Uluslararası Sosyal Araştırmalar Dergisi, 2 (9), 2009, s. 144- 158.

Güler, Ali, “Osmanlı Devleti'nin Son Yıllarında Türkiye'nin Demografik Durumuna Genel Bir Bakış",Osmanlı, C. 4, Yeni Türkiye Yayınları, Ankara 1999, s. 568- 571.

Gülsoy, Ufuk, "Islahat Fermanı”, Diyanet Vakfi Islam Ansiklopedisi, Cilt: 19, Türkiye Diyanet Vakfı Yayınları, İstanbul 1999, s. 185- 189.

İlgürel, Mücteba, "Osmanlılarda Eşkıyalık Hareketleri”, Türkiye Diyanet Vakfi İslam Ansiklopedisi, C. 11, Türkiye Diyanet Vakf1 Yayınları, İstanbul 1995, s. 467- 468.

İpek, Nedim, "Orta ve Doğu Karadeniz Limanlarındaki Ticari Faaliyetlerin Kent Nüfusuna Etkisi (1838- 1900)”, Uluslararası Karadeniz Incelemeleri Dergisi, 1(1), 2006, s. 107- 121.

Kütükoğlu, Mübahat, Osmanl- Ingiliz Ikktisadi Münasebetleri (cilt: 2), Edebiyat Fakültesi Basımevi, İstanbul 1976.

Keyder, Ç. vd., Osmanlı İmparatorluğu'nda Liman Kentleri: Bazı Kuramsal ve Tarihsel Perspektifler, Keyder vd. (ed.) Doğu Akdeniz'de Liman Kentleri 1800- 1914 içinde, Tarih Vakf1 Yurt Yayınları, İstanbul 1994, s. 121- 157.

Keyder, Ç., Belle epoque ve liman kentleri. B. Kolluoğlu ve M. Toksöz, Osmanlılardan Günümüze Doğu Akdeniz Kentleri içinde, Türkiye İş Bankası Kültür Yayınları, İstanbul 2015, s. 17- 28.

Kılıç, Orhan, Eskiçağdan Yakınçağa Genel Hatlarıyla Dünyada ve Osmanlı Devleti'nde Salgın Hastalıklar, Firat Üniversitesi Basımevi, Elazığ 2004.

Kılıç, Orhan, "Osmanlı Devleti'nde Meydana Gelen Kıtlıklar", Uluslararası Sosyal Araştırmalar Dergisi, 2 (9), 2002, s.1- 18.

Kiel, Machiel, "Tesalya", Türkiye Diyanet Vakfi İslam Ansiklopedisi, C.40, Türkiye Diyanet Vakf1, İstanbul 2011, s. 522- 526.

Kodaman, Bayram, Abdülhamit Devri Eğitim Sistemi, Türk Tarih Kurumu, Ankara 1991.

Kocabaşoğlu, Uygur, Majestelerinin Konsolosları, İletişim Yayınları, İstanbul 2004.

Karal, Enver Ziya, Osmanlı İmparatorluğunda İlk Nüfus Sayımı 1931, DİE, Ankara 1995.

Mazak, Mehmet ve Doğan, Aylin (drl.), Osmanlı Arşiv Vesikaları ve Fotoğraflarla Mersin Liman Tarihi, Yeditepe Yayınları, İstanbul 2014.

Okur, Mehmet, “Türkiye'de milli ve modern bir eğitim sistemi oluşturma çabaları (1920-1928)", Çağdaş Türkiye Tarihi Araştırmaları Dergisi, 4 (11), 2005, s. 93- 109. 
Öztürk, Selda, Mühimme Defteri’nde Bolu Sancağı ve Bolu'da Eşklyalık, Yayımlanmamış Yüksek Lisans Tezi, Abant İzzet Baysal Üniversitesi, Sosyal Bilimler Enstitüsü, Bolu 2010.

Özcan, Selim, Tanzimat Döneminde Sinop'un Sosyal Ekonomik Durumu, Yayımlanmamış Yüksek Lisans Tezi, Ondokuz Mayıs Üniversitesi, Sosyal Bilimler Enstitüsü, Samsun 2007.

Sami, Şemsettin, “Golos”Kamûsu'l- Alâm, C. 3, Mihran Matbaaası, İstanbul 1314.

Serbestoğlu, İbrahim, "Yunanistan'a Geçiş Sürecinde Tesalya Müslümanlarının Durumu" Belleten, 78 (283), 2014, s. 1075- 1098.

Serbestoğlu, İbrahim, “1897 Türk-Yunan Savaşı’nda Ecnebilerin Zararlarının Tazmini Meselesi”. OTAM, 34, 2013, s. 223- 243.

Serbestoğlu, İbrahim ve Tümtaş, Mim Sertaç, “ II. Abdülhamit Döneminde Bir Liman Kenti: Dedeağaç”, Ubtas Bled, Slovenya 2017.

Savaş, Ali İbrahim, "Konsolos", Türkiye Diyanet Vakfi İslam Ansiklopedisi, C. 26, Türkiye Diyanet Vakfi, İstanbul 2002, s. 178- 180.

Soyucak, Ali Rıza, Konya ve Çevresinde Eşkyyalık Hareketleri (1640- 1675), Yayımlanmamış Yüksek Lisans Tezi, Selçuk Üniversitesi, Sosyal Bilimler Enstitüsü, Konya 1997.

Sungur, Mutullah, “XIX. Yüzy1lda Osmanlı Devleti’nde Nüfus ve Nüfus Sayımları” Osmanl, C. 4 Yeni Türkiye Yayınları, Ankara, s. 558- 556.

Şimşek, Fatma, 19. Yüzyılın İkinci Yarısında Osmanlı Liman Kentlerinde Karantina Uygulaması, Ş. Kantarcı, F. Şimşek (ed.), Berna Türkdoğan Armağan Kitabı (s. 399- 412) içinde, Sonçağ Yayınları, Ankara 2015.

Turhan Sarıköse, Selma, XIX. Yüzyılda Çukurova'da Doğal Afetler ve Salgın Hastalıklar, Yayımlanmamış Doktora Tezi, Selçuk Üniversitesi, Sosyal Bilimler Enstitüsü, Konya 2013.

Tuğlac1, Pars, Osmanlı Şehirleri Tarihi, Milliyet Yayınları İstanbul 1985.

Tekeli, İlhan, Kent Planlaması ve Kent Araştırmaları, Cumhuriyet Döneminde Türkiye'de Bilim: Sosyal Bilimler II. Türkiye Bilimler Akademisi, Ankara 1998, s. 302- 267.

Ulutürk, Muammer, “Osmanlı Devleti’nde Millet Sistemi”, Tefekkür Dergisi, 51, 2012, s. 1- 4.

Ürekli, Fatma, Tanzimat Dönemi Osmanlı Eğitim Sistemi ve Kurumları. Manas Üniversitesi Sosyal Bilimler Dergisi, 3, 2002, s. 382- 406.

Ünlü, Tülin Selvi ve Göksu, Emel, “Osmanlı'dan Ulus-Devlete Doğu Akdeniz Liman Kentlerinde mekâna müdahale ve kent kimliğindeki değişim- mersin ve volos Örneği”, METU JFA, 1(5), 2018, s. 1- 38.

Ünlü, Tülin Selvi, On Dokuzuncu Yüzyıldan Yirminci Yüzyıla Doğu Akdeniz Liman Kentlerinde Mekânın Dönüşümü: Volos Patras ve Mersin, Yayımlanmamış Yüksek Lisans Tezi, Dokuz Eylül Üniversitesi, Fen Bilimleri Enstitüsü, İzmir 2016.

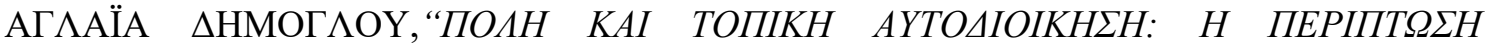

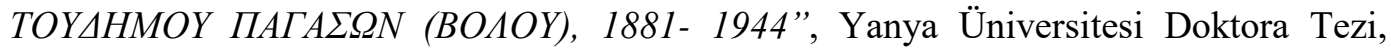
Yanya, 2003. 


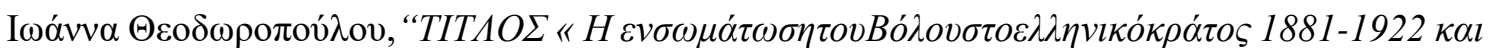

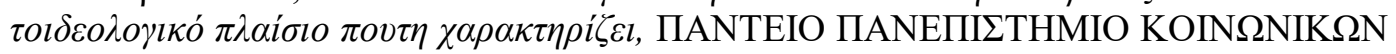

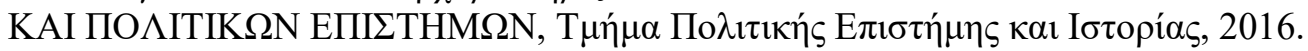

\section{Internet Kaynaklart}

http://www.bakisarisakal.com/lozan.html 